\title{
Determinan Akuntabilitas Pengelolaan Keuangan Desa di Kecamatan Tanawawo
}

\author{
Fransiskus Marlon Reu, Lodovicus Lasdi \\ Magister Akuntansi, Universitas Katolik Widya Mandala Surabaya \\ l. Kalisari Selatan No.1 Kalisari, Pakuwon City, Kec. Mulyorejo, Kota SBY, Jawa Timur 60112
}

\section{Kata kunci:}

Kompetensi aparatur, partisipasi masyarakat, pengendalian intern, pengelolaan keuangan, akuntabilitas desa, penerapan Siskeudes

\author{
Keywords: \\ Apparatus competence, \\ community participation, \\ internal control, financial \\ management, village \\ accountability, Siskeudes \\ application.
}

Corresponding author: lodovicus@ukwms.ac.id

\section{ABSTRAK}

Penelitian ini bertujuan untuk mengetahui pengaruh kompetensi aparatur desa, sistem pengendalian intern, partisipasi masyarakat desa dan penerapan Siskeudes terhadap akuntabilitas pengelolaan keuangan desa. Metode pengumpulan data dalam penelitian ini menggunakan kuesioner yang disebarkan langsung kepada responden dengan jumlah sampel 88 perangkat desa yang terdiri dari 8 desa. Objek dalam penelitian ini adalah seluruh pemerintah desa yang ada di wilayah Kecamatan Tanawawo. Analisis data dilakukan dengan menggunakan metode linier berganda. analisis regresi Hasil penelitian menunjukkan bahwa kompetensi aparatur desa dan sistem pengendalian intern berpengaruh positif terhadap akuntabilitas pengelolaan keuangan desa, sedangkan variabel partisipasi masyarakat desa dan penerapan Siskeudes tidak berpengaruh terhadap akuntabilitas pengelolaan keuangan desa dalam Tanaw wilayah Kecamatan Tanawawo. Implikasi penelitian ini khususnya bagi perangkat desa di Kecamatan Tanawawo diharapkan lebih baik dalam pertanggungjawaban pengelolaan keuangan desa, memberikan masukan kepada pemerintah kabupaten Sikka mengenai efektifitas penggunaan aplikasi Siskeudes di kabupaten Tanawawo, agar kedepannya aplikasi Siskeudes dapat digunakan sepenuhnya di daerah ini dan dapat menyederhanakan sistem pembukuan dan pengeluaran desa. Selain itu, perangkat desa juga diharapkan mampu melibatkan masyarakat desa dalam segala pengambilan keputusan yang berkaitan dengan kepentingan dan kemajuan desa dan masyarakat pada umumnya. Keterbatasan dalam penelitian ini terletak pada metode penelitian yang belum dapat menggambarkan secara utuh kondisi sebenarnya dari objek penelitian, sehingga penelitian selanjutnya diharapkan dapat menambahkan metode lain seperti wawancara.

\section{ABSTRACT}

This study aims to determine the effect of village management apparatus competence, internal control system, community participation, and Siskeudes application on village financial management accountability. This study used questionnaires distributed directly to respondents with a total sample of 88 village officials consisting of 8 villages. The object in this study was all village governments in the Tanawawo District area. Data analysis was performed using multiple linear regression analysis. The results showed that the village management apparatus competence and the internal control system positively affected the accountability of village financial management. In contrast, the village community participation variables and the Siskeudes application did not affect the accountability of village financial management in the Tanawawo District area. The implications of this study specifically for village officials in the Tanawawo District are expected to be better accountable for village financial management, provide input to the Sikka district government regarding the effectiveness of using the Siskeudes application in the Tanawawo district. So that in the future, the Siskeudes application can be fully used in this area and can simplify the bookkeeping system and village expenditures. The village apparatus is expected to involve the village community in all decision-making related to the interests and progress of the village and society. The limitation in this study lies in the research method that has not been able to describe the actual condition of the object of research fully. Further research is expected to add other methods such as interviews. 
Studi Akuntansi \& Keuangan Indonesia

\section{Pendahuluan}

Desa merupakan sebuah unit organisasi terkecil dalam tatanan pemerintah yang tumbuh bersamaan dengan hukum dan adat istiadat setempat. Desa sendiri memiliki kewenangan untuk kemudian mengatur, mengurus dan mengelola tata pemerintahan desa yang disesuaikan dengan kepentingan masyarakat dalam rukun atau wilayah desa tersebut sesuai hukum adat yang melekat dalam wilayah tatanan Pemerintah Negara Kesatuan Republik Indonesia. Desa sebagai unit organsiasi pemerintahaan diharapkan untuk tetap mampu dan berkontribusi dalam memberikan peranan dan fungsi untuk menjawab latar belakang pemikiran dan kepentingan masyarakat desa yang tentunya berbeda-beda. Hingga kini pemerintahaan Indonesia terus berupaya untuk melakukan pemerataan pembangunan, mulai dari unit terkecil dalam tatanan pemerintaan yaitu desa. Dalam kaitannya dengan desa, kemudian munculah istilah perangkat desa yang kemudian didefinisikan sebagai kumpulan dari beberapa individu yang secara bersamaan membantu dan bekerjasama dengan pemimpin desa untuk bersama-sama menajalankan fungsi serta tanggungjawab team aparatur desa dalam kaitannya dengan implementasi pelaksanaan teknis dari semua fungsi dan tanggungjawabnya sebagai seorang pemimpin desa. Sebagai salah satu bentuk nyata dari upaya tersebut pada era kepemimpian Presiden Joko Widodo, beliau membuat dan menciptakan Undang-Undang Nomor 6 Tahun 2014 terkait keuangan dana desa baik dari sisi pengelolaan dan kebijakan dengan harapan dapat membantu aparatur desa dalam implementasi dan penerapan terkait pemanfaatan dana desa tersebut.

UU nomor 6 tahun 2014 merupakan sebuah terobosan terbaru diberikan oleh Pemerintah Jokowi sebagai suatu upaya untuk mendukung desa agar lebih berkontribusi dalam pembangunan yaitu dengan menciptakan sistem terkait pengelolaan dan pemanfaatan dana desa yang lebih baik lagi. Sistem Alokasi Dana Desa (ADD) juga diharapkan dapat menjadi sebuah komitmen dari pemerintah untuk secara konsisten dan bertahap dalam pemerataan pembangunan yang dimulai dari unit pemerintahan terkecil yaitu desa sendiri. Alokasi dana desa yang terus mengalami peningkatan dari sisi anggaran juga merupakan sebuah bukti serius dalam komitmen pemerintah untuk secara berangsur melakukan pemerataan pembangunan tersebut. Hal tersebut juga dapat dilihat dari data anggaran Kenaikan ADD secara signifikan dan bertahap mengalami peningkatan yang lumayan fluktuatif, dimana anggaran yang dialokasikan pada tahun 2015 sebesar Rp20,67 triliun terus mengalami kenaikan sebesar Rp46,98 triliun, pada tahun 2017, 2018 juga kembali mengalami peningkatan sebesar Rp60 triliun, dan kemudian mengalami kenaikan lagi pada tahun 2019 yang mencapai Rp70 triliun (Kementerian Keuangan, 2017).

Berdasarkan data jumlah alokasi dana desa dan anggaran yang dialokasikan pemerintah pusat dalam mendukung rangkaian program serta kebijakan pemerintah desa dalam pembangunan tersebut, tentunya juga menuntut pihak desa untuk lebih bertanggung jawab terhadap anggaran dan realisasi dari anggaran tersebut serta secara keseluruhan mampu bersinergi dan melakukan pengelolaan keuangan desa yang lebih baik lagi. Untuk mengontrol besarnya dana desa tersebut, Kementrian Keuangan telah mengatur beberapa laporan yang wajib dilaporkan oleh aparat desa, seperti Realisasi Pelaksanaan Anggaran (RPA), Anggaran Pendapatan Belanja (APB), Laporan Pertanggungjawaban (LPJ), Realisasi Pelaksanaan APB Desa yang dilaporkan setiap 6 bulan, Membuat laporan pertanggungjawaban aparatur desa, Realisasi tahunan dari anggaran desa dan beberapa laporan lainya yang tertuang dalam Undang-undang. Latar belakang UU tersebut merupakan salah satu bukti nyata dari penerapan atau pemanfaatan UU No 6 Tahun 2014 tentang desa, maka diperlukan pembenahan keuangan desa yang berpedomam pada UU, peraturan maupun kebijakan yang telah diatur sebelumnya yang dapat digunakan dalam segala rangkain kegiatan desa seperti merencanakan, mengendalikan serta memperleh keputusan akhir terkait pengelolaan anggaran desa yang dapat berguna bagi masyarakat dan pemerintah pusat sebagai principle.

Adapun beberapa masalah yang masih menjadi perhatian khusus dalam lingkup akuntansi pemerintahaan adalah terkait pengelolaan dana desa yaitu tingginya tuntutan mengenai akuntabilitas pengelolaan dana desa yang segera mungkin harus menjadi fokus pembenahan bagi aparatur desa. Luthfiani et al., (2020) menjabarkan bahwa akuntabilitas sendiri merujuk pada suksesnya pemberian segala rangkain info publik atas segala rangkaian pertanggungjawaban aparatur desa dalam kaitannya dengan visi misi desa dan negara yaitu meciptakan desa yang lebih maju, mandiri, sejahtera, adil, demokratis serta mampu dalam mengelola, mengatur serta mengurus diri sendiri dalam mewujudkan pembangunan dan infrastruktur desa yang lebih baik.

Akuntabilitas merupakan suatu bentuk pertanggungjawaban atau keharusan seseorang yang diberikan kepercayaan dalam pengelolaan suatu organisasi atau pemerintah desa dalam melaksanakan dan mengimplementasikan segala tanggung jawab serta kinerja aparatur desa yang diukur sesuai dengan standar 
Studi Akuntansi \& Keuangan Indonesia

tertentu (Luthfiani et al., 2020). Indikator akuntabilitas dalam penelitian ini didasarkan pada Peraturan Menteri Dalam Negeri (Permendagri) Nomor 113 tahun 2014 tentang Pengelolaan Keuangan Desa yang meliputi perencanaan, pelaksanaan, penatausahan, pelaporan dan pertanggungjawaban. Dalam kaitannya pemanfaatan penerapan pengelolaan keuangan desa yang sesuai dengan standar akuntabilitas, terdapat beberapa masalah yang diyakini mempengaruhi penerapan dan impilikasi akuntabilitas keuangan desa hingga saat ini yaitu kompetensi pengelola desa, sistem pengendalian internal, partisipasi masyarakat dan aplikasi sistem keuangan desa.

Kompetensi pengelola desa merupakan salah satu faktor penting dan utama dalam menilai keberhasilan dan kinerja seseorang. Kompotensi merupakan suatu dasar dan wajib dalam penilaian yang harus dimiliki oleh seorang pemimpin maupun pengelola desa dalam kaitannya dengan pengelolaan dana desa. Dalam kaitannya dengan kompetensi pengelola desa, (Luthfiani et al., 2020) menjabarkan jika ukuran kompetensi seseorang didasarkan pada sebuah pemahaman (knowledge), kecakapan dan keterampilan yang dinilai dengan beberapa aspek teknis. Kompetensi sendiri harus dimiliki oleh kepala desa maupun pengelola desa lain untuk menjadi landasan awal dalam menjalankan fungsi serta tanggungjawabnya sebagai aparat desa. Kompetensi pengelola desa hingga kini masih tergolong rendah. Hal tersebut dikarenakan dengan masih rendahnya tingkat sumber daya manusia (SDM) pengelola desa, kurangnya keahlian tertentu serta minimnya pengetahuan pengelola desa terkait akuntabilitas pengelolaan keuangan desa. Penelitian sebelumnya terkait pengaruh kompetensi pengelola desa juga telah dilakukan oleh Karyadi (2019) dan Mada et al., (2017) yang memberikan bukti bahwa komptensi pengelola desa berpengaruh positif dan signifikan terhadap akuntabilitas pengelolaan keuangan desa.

Faktor berikutnya yang juga diyakini berkaitan dengan pengelolaan keuangan desa yaitu sistem pengendalian internal (SPI). Peraturan Pemerintah (PP) No. 60 menjabarkan lebih lanjut bahwa sistem pengendalian internal (SPI) merupakan sebuah bentuk control yang dilakukan oleh pemerintah pusat dalam kaitanya dengan fungsi pengawasan, guna memperoleh sebuah kepercayaan bahwa segala rangkaian organisasi telah berjalan dan dilakukan dengan berpedoman pada undang-undang. SPI sendiri pada akhirnya merupakan salah satu kunci penting dalam meningkatkan akuntabilitas yang dilihat berdasarkan opini akhir dari BPK yang merupakan indikator penting pemanfaatan pengelolaan keuangan publik. SPI memiliki cakupan yang cukup kecil dan terkonsentrasi pada pengendalian yang lebih baik. SPI pada pemerintah desa juga pada dasarnya mencakup wilayah yang lebih kecil dengan fungsi monitoring, kontrol yang terpusat dan dilakukan oleh Badan Pemusyawaratan Desa (BPD) dalam kaitannya dengan mengontrol kinerja kepala desa untuk mengurangi dan meminimalisir terjadinya kecurangan dan penggelapan dana desa. Hingga kini penerapan sistem pengendalian pemerintah belum sepenuhnya mampu menjelaskan kualitas dari sistem pengendalian internal yang sesuai dengan pedoman dan standar undang-undang. Masalah diatas memberikan bukti bahwa Sistem Pengendalian Internal pemerintahan dalam hal ini pemerintah desa masih kurang efektif. Penelitian terkait dengan sistem pengendalian internal juga telah dilakukan oleh beberapa peneliti diantaranya, Karyadi (2019); Sweetania et al., (2019); Yesinia et al., (2018) memberikan bukti bahwa sistem pengendalian internal berpengaruh positif dan signifikan terhadap akuntabilitas pengelolaan keuangan desa.

Partisipasi masyarakat desa merupakan salah satu masalah yang menjadi fokus penting dalam meningkatan akuntabilitas. Partisipasi masyarakat desa diyakini dapat menjadi sebuah indikator penting dalam mewujudkan angka partisipatif seluruh elemen desa serta mampu mewakili aspirasi masyarakat miskin terkait pembangunan desa Mada et al., (2017). Apabila ditelusuri lebih jauh partisipasi masyarakat desa sendiri merupakan suatu akses bagi masyarakat desa untuk mengetahui perkembangan sarana prasarana desa yang ada dan juga merupakan sebuah wadah dalam menampung segala aspirasi masyarakat desa terkait pengelolaan dan implementasi dari pengelolaan keuangan desa secara umum yang kemudian dijabarkan dalam pasal 54 UU No 16 Tahun 2014, dimana menjelaskan bahwa partisipasi elemen desa merupakan suatu bentuk wadah yang menerima serta mengumpulkan aspirasi-aspirasi masyarakat desa yang berbeda yang terdiri atas badan pengawas desa, aparatur desa serta unsur tokoh adat dan masyarakat pada umumnya untuk kemudian melakukan perbaikan yang bersifat membangun kepentingan desa. Masalah terkait partisipasi masayarakat desa juga sering ditemui, dimana masyarakat desa yang kurang partispatif serta memiliki pandangan bahwa suara dan aspirasi mereka tidak penting untuk memberikan masukan kepada aparat desa setempat. Selain itu, adanya sistem tebang pilih juga sering ditemui, dimana terdapat beberapa masyarakat desa tertentu yang dipilih untuk mewakili masyarakat desa secara umum, dan rata-rata mereka yang dilibatkan adalah pendukung kepala desa tersebut, sedangkan mereka yang memiliki pandangan berbeda jarang untuk diikutsertakan karena dianggap kontra atau menentang dengan kebijakan aparat desa. Menurut Badan 
Studi Akuntansi \& Keuangan Indonesia

Pengawasan Keuangan Pemerintah (BPKP) fenomena lain yang juga terkait pengelolaam alokasi dana desa yaitu terdapat penyimpangan alokasi dana desa sekitar 5-10\% dari total alokasi dana desa yang ada, sehingga dibutuhkan peran dan partisipasi masyarakat desa secara bersinergi untuk bersamaan mengelola keuangan desa tersebut. Penelitian terkait partisipasi masyarakat juga telah dilakukan oleh Mada et al., (2017) yang membuktikan bahwa partisipasi masyarakat berpengaruh positif dan signifikan terhadap akuntabilitas pengelolaan keuangan desa.

Faktor terakhir yang merupakan salah satu strategi yang dilakukan oleh Badan Pengawasan Keuangan Pemerintah (BPKP) yang berfungsi sebagai pengawas jalannya pengelolaan keuangan yaitu dengan membuat dan menciptakan aplikasi Sistem Keuangan Desa (Siskeudes) dengan harapan dapat mempemudah pengelolaan keuangan desa yang sebelumnya hanya sebatas formalitas kedalam suatu aturan yang mengacu pada aturan dan undang-undang yang ditetapkan oleh pemerintah. Aplikasi siskeudes relatif mudah digunakan untuk mengakomodir dan menjawab kebutuhan administrasi dan penatausahaan terkait akuntabilitas pengelolaan keuangan desa. Permasalahan terkait penerapan Siskeudes tersebut tentunya menjadi masalah bagi masyarakat desa yang belum terbiasa menggunakan komputer sebagai alat dalam mempertanggungjawabkan pengelolaan keuangan desa tersebut. Selain itu juga permasalahan yang terjadi terkait aplikasi Siskeudes adalah berkaitan dengan ketersediaan jaringan internet yang belum mampu mengakses topografi desa yang masih terpencil sehingga menyebabkan belum adanya pemerataan penggunaan aplikasi Siskeudes. Pelatihan penggunaan aplikasi yang dijanjikan secara berkala oleh pemerintah pusat juga apakah sudah sesuai dengan rencana tersebut dan telah diikuti oleh semua elemen desa hingga ke desa dengan letak topografi desa yang ekstrem atau susah untuk diakses. Penelitian terkait aplikasi siskeudes juga telah dilakukan oleh Luthfiani et al., (2020) yang membuktikan bahwa aplikasi Siskeudes berpengaruh positif dan signifikan terhadap akuntabilitas pengelolaan keuangan desa.

Penelitian ini mengambil objek penelitian pada Kecamatan Tanawawo, yang berada di wilayah Kabupaten Sikka, Nusa Tenggara Timur (NTT). Provinsi Nusa Tenggara Timur merupakan salah satu provinsi yang berada di ujung timur Indonesia, yang tercatat memiliki kasus penyimpangan dan korupsi anggaran dana desa relatif banyak, dimana jika ditelusuri lebih jauh dari 2016 hingga 2019 terdapat 22 pimpinan desa yang telah dijatuhi hukuman bersalah dalam kasus penyelewengan anggaran desa dan 6 kepala desa lainnya sedang menunggu proses pengadilan saat ini. Penelitian ini berfokus pada objek pemerintahaan desa di Kecamatan Tanawawo, Kabupaten Sikka. Kecamatan Tanawawo sendiri adalah sebuah kecamatan dengan tata letak berada di ujung barat Kabupaten Sikka, Provinsi Nusa Tenggara Timur yang masih jauh dari kata pemerataan dan kesejahteraan pembangunan apabila dibandingkan dengan kecamatan lain di wilayah kabupaten Sikka. Hal tersebut dikarenakan akses topografi dan letak desa yang masih sangat jauh dari akses kota. Kecamatan Tanawawo sendiri memilik 8 desa yang tersebar di wilayah kecamatan ini. Teracatat pada tahun 2019 terjadi kasus penggelapan dana desa yang dilakukan oleh seorang kepala desa Loke yang juga termasuk dalam wilayah kecamatan ini, dimana kepala desa tersebut terbukti melakukan korupsi dana desa untuk pengadaan listrik tenaga surya di desa Loke dengan total kerugian negara sebesar 116,78 juta.

Tujuan dari penelitian ini adalah dapat memberikan pandangan dan bukti empiris terkait beberapa faktor yang diyakini mempengaruhi dan berkaitan dengan akuntabilitas pengelolaan keuangan desa di kecamatan Tanawawo kepada Pemerintah Kabupaten Sikka baik pemerintah desa dan aparat desa sehingga dapat meningkatkan kualitas pengelolaan keuangan desa di tahun-tahun berikutnya. Selain itu penelitian ini juga diharapkan dapat memberikan saran dan masukan dalam kaitanya dengan penerapan dan evaluasi kebijakan pemerintah dalam kaitanya dengan akuntabilitas pengelolaan keuangan desa

Berdasarkan penjelasan penelitian tersebut, disimpulkan bahwa terdapat inkonsistensi dari penelitian terdahulu, sehingga peneliti ingin melakukan penelitian serupa terkait faktor-faktor yang mempengaruhi akuntabilitas pengelolaan keuangan desa dengan menggunakan variabel independen yaitu kompetensi aparat pengelola desa, sistem pengendalian internal, partisipasi masyarakat desa dan penggunaan aplikasi Siskeudes. Perbedaan penelitian ini dengan penelitian terdahulu terdapat pada penggunaan dan penambahan variabel partisipasi masyarakat dan penggunaan aplikasi Siskeudes yang masih jarang diteliti oleh peneliti sebelumya dalam kaitannya dengan akuntabilitas pengelolaan keuangan desa serta pemilihan objek penelitian yang berbeda pula, secara khusus di wilayah NTT dengan jumlah angka penyimpangan alokasi dana desa yang lumayan tinggi di wilayah NTT sehingga masih perlu dilakukan guna memperoleh bukti empiris terkait pengaruh kompetensi aparat pengelola desa, sistem pengendalian internal, partisipasi masyarakat desa dan 
Studi Akuntansi \& Keuangan Indonesia

penggunaan aplikasi Siskeudes terhadap akuntabilitas pengelolaan keuangan desa di wilayah kecamatan Tanawawo.

\section{Telaah Literatur dan Pengembangan Hipotesis}

\section{Agency Theory}

Jansen dan Meckling (1976) menjelaskan bahwa teori keagenan pada dasarnya muncul akibat adanya kontrak atau konflik antara prinsipal dan agen, dimana prinsipal memberikan amanat kepada agen berupa beberapa fungsi pertumbuhan perusahaan kedepannya, dimana agen diharuskan dapat mengembangkan perusahaan ke arah profit yang lebih baik. Teori keagenan mendefinisikan terdapatnya perjanjian kedua pelaku utama yaitu investor dan manajer, dimana pada kenyataanya manajer diharapkan mampu menghasilkan profit sebesar-besarnya untuk kepentingan pemilik perusahaan (prinsipal) sedangkan agen juga memiliki kepentingan pribadi guna meningkatkan keuntungan pribadinya dengan memanfaatkan peluang tersebut.

Keterkaitan agency theory dalam penelitian ini dapat dilihat dari sisi pelaporan keuangan pemerintah atau pemerintahan desa secara khusus dimana dalam hal ini aparat desa bertindak sebagai pihak agent yang memiliki amanah atau kepercayaan dalam mengelolah tatanan desa dan berkewajiban untuk mengungkapkan segala bentuk informasi terkait pengelolaan dana desa yang dibutuhkan oleh pihak principal (pemilik) yaitu masyarakat. Hal tersebut kemudian dijelaskan dalam UU No 32 Tahun 2004 tentang Pemerintahan dimana dalam pasal tersebut dijelaskan bahwa kepala desa sebagai pemimpin dalam lingkup wilayah desa dipilih oleh rakyat dari rakyat dan untuk kepentingan rakyat umum seutuhnya. Pendelegasian tugas serta kepercayaan yang diberikan oleh masyakarat selaku principal kepada agent atau kepala desa tersebut kemudian menyebabkan munculah konflik kepentingan atau asimetris informasi yang menyebabkan masyarakat sebagai principal tidak mengetahui secara keseluruhan terkait akuntabilitas pengelolaan keuangan desa di wilayah tersebut. Asimetris informasi yang muncul akibat adanya konflik kepentingan terkait akuntabilitas pengelolaan keuangan desa tersebut lebih lanjut akan menyebabkan semakin besarnya peluang dalam penggelapan atau penyelewengan alokasi dana desa yang semakin marak terjadi hingga saat ini.

Berkaitan dengan pendelegasian tugas dari masyarakat kepada pemerintah desa, maka diperlukan segala informasi terkait pengelolaan keuangan desa yang harus dapat dipertanggungjawabkan melalui laporan keuangan yang transparan dan akuntabel atau sesuai dengan peraturan perundang-undangan yang berlaku. Pemerintah desa dalam hal ini berperan sebagai agen diharapkan dapat menyelaraskan fungsi serta tanggungjawab kepada masyarakat selaku principal dalam kaitannya dengan pengelolaan dan penyajian laporan keuangan desa yang lebih baik.

Kompetensi aparat pengelolaan keuangan desa, sistem pengendalian internal, partisipasi masyarakat desa dan penggunaan aplikasi siskeudes dalam penelitian ini diyakini memiliki pengaruh terhadap akuntabilitas pengelolaan keuangan desa. Hubungan antara keempat variabel tersebut dalam kaitannya dengan agency theory diharapkan dapat menjadi sebuah solusi atau jembatan untuk meminimalisir adanya perbedaan informasi yang ada pada principle dan agent atau dalam lingkup desa antara masyarakat desa dan pimpinan desa atau kepala desa tersebut.

\section{Pengaruh Kompetensi Aparat Pengelolah Desa Terhadap Akuntabilitas Pengelolaan Keuangan Desa}

Kompeten adalah suatu kemampuan seseorang dalam melaksanakan wewenang pekerjaan yang diberikan kepadanya sesuai dengan ketentuan yang telah ditetapkan. Menurut Widyatama et al., (2017) kompeten atau kompetensi berkaitan dengan kemampuan individu dalam kaitanya dengan keahlian dan pengetahuan yang dinilai atau diukur dengan suatu penilai tertentu. Kompetensi mampu dinilai dengan menggunakan pengukuran dari ketiga elemen tersebut. Seorang individu yang kompeten dapat dilihat dan dinilai dari segala keberhasilan pekerjaan yang tidak luput dari pengaruh lingkungan serta etos kerja dalam organisasi tersebut. Hal tersebut menyimpulkan bahwa, kompeten terdiri atas pengetahuan, kecakapan dan kemampuan yang diperlukan untuk melakukan suatu fungsi pekerjaan. Kompeten seorang aparat desa selain dilihat dari keberhasilan dalam mengelolah tatanan desa yang lebih baik, juga dapat dilihat dari sisi keberhasilan dalam pengambilan keputusan dimana hal tersebut berkaitan dengan latar belakang pendidikan aparat desa, pengalaman dan juga kemampuan yang melekat pada orang tersebut.

Jensen dan Meckling (1976) menjabarkan keterkaitan antara agency theory dikarenakan adanya hubungan timbal balik antara pemilik (principle) dan manajer (agen), dimana agen dalam hal ini bertugas 
Studi Akuntansi \& Keuangan Indonesia

dalam mengelolah perusahaan sehari-hari dan lebih memahami lingkup perusahaan secara luas. Kaitannya dengan pemerintah desa adalah masyarakat desa sebagai principle menyerahkan segala kepercayaan dan wewenang dalam mengelola pemerintah kepada aparatur desa (agen). Kompetensi merupakan sebuah keharusan yang dibutuhkan oleh seseorang secara khusus aparatur desa untuk mampu menyelaraskan fungsi serta tanggung jawabnya sebagai aparatur desa. Kompetensi merupakan sebuah kunci utama keberhasilan aparatur pengelola desa dalam kaitannya dengan mewujudkan pengelolaan keuangan desa yang lebih baik yang sesuai dengan kaidah peraturan perundang-undangan yang ada.

Kompetensi diyakini sebagai salah satu modal utama yang dibutuhkan oleh aparatur desa dalam meningkatkan akuntabilitas pengelolaan keuangan desa, dimana semakin kompeten seseorang aparat desa dalam melaksanakan tugas dan tanggung jawabnya, maka akan mewujudkan akuntabilitas pengelolaan keuangan desa yang lebih baik. Kompetensi dalam kaitannya dengan pemerintah desa merupakan sebuah ukuran kemampuan yang dimiliki oleh aparat desa untuk mendukung segala kesuksesan pekerjaan yang didelegasikan oleh masyarakat sesuai dengan ketentuan perundang-undangan. Penelitian ini mengukur kompetensi aparat pengelola keuangan desa dengan beberapa aspek yang dipadu dalam enam pertanyaan kunci yang dapat menjabarkan kompetensi aparat desa dari sisi kemampuan, pengetahuan, pemahaman serta pelatihan dan etika yang diyakini memiliki pengaruh terhadap akuntabilitas pengelolaan keuangan desa. Dalam penelitian Mada et al., (2017); Karyadi (2019); Luthfiani et al., (2020) memberikan bukti bahwa kompetensi merupakan suatu faktor yang dapat mewujudkan akuntabilitas pengelolaan keuangan desa yang lebih baik. Berdasarkan penjelasan tersebut, maka hipotesis yang diajukan adalah

\section{H1: Kompetensi Aparat Pengelolah Desa Berpengaruh Positif Terhadap Akuntabilitas Pengelolaan} Keuangan Desa di Kecamatan Tanawawo

\section{Pengaruh Sistem Pengendalian Internal Terhadap Akuntabilitas Pengelolaan Keuangan Desa}

Menurut Peraturan Pemerintah (PP) Nomor 50 Tahun 2008 Sistem Pengendalian Internal (SPI) adalah sebuah proses integral yang menghubungkan sebuah tindakan dan kegiatan yang dilakukan secara berkala oleh pimpinan dan keseluruhan karyawan dalam mewujudkan sebuah keyakinan yang memadai terkait keandalan pelaporan keuangan, pengamanan aset negara dan ketaatan terhadap peraturan perundangundangan untuk mencapai tujuan organisasi. SPI merupakan sebuah prosedur yang dibuat sedemikian rupa dalam menjamin terwujudnya tujuan organisasi dan meminimalisir adanya kesalahahan dan penyelewengan tertentu. Agen dalam hal ini manajer diharapkan mampu menilai pengendalian yang dibuat apakah sudah mampu meminimalisir semua permasalahan yang akan dihadapi.

SPIP atau sistem pengendalian internal pemerintah adalah suatu alat pengendalian sistem internal yang dilaksanakan pada semua lingkungan pemerintah pusat dan pemerintah daerah yang kemudian tertuang dalam PP No.60 tahun 2008. SPI adalah suatu bentuk control dan pengawasan yang dilakukan dengan tujuan meminimalisir adanya kesalahan dalam pelaksanaan fungsi serta tanggungjawab organisasi seperti kecurangan dan penyelewengan aset negara. Dalam hubungannya dengan agency theory semakin baiknya sistem pengendalian internal pemerintah desa maka hal tersebut dapat meminimalisir adanya konflik kepentingan dan asimetris informasi antara agent dan principal. Dalam kaitannya dengan pemerintahan desa, penelitian ini menilai dan mengkaji SPI dengan lebih berfokus pada lini yang lebih kecil yaitu pemerintahaan desa dan Badan Pengawas Desa (BPD). BPD merupakan sebuah lembaga desa yang memiliki fungsi untuk melaksanakan pengawasan dalam kinerja aparatur desa baik terkait pengelolaan dan implementasi dari alokasi dana desa.

Menurut PP No. 60 Tahun 2008, tujuan SPI yaitu untuk mampu memberikan penilaian tentang keefektifan dan efisiensi segala rangkaian proses keuangan seperti laporan keuangan yang bebas dari salah saji, aset negara yang dilindungi dan bebas dari kasus kecurangan dan penggelapan serta segala aktivitas yang didasari pada undang-undang yang berlaku. Beberapa elemen untuk mengukur sistem pengendalian internal pemerintah, yaitu lingkungan pengendalian, penilaian risiko, kegiatan pengendalian, informasi dan komunikasi dan pemantauan pengendalian internal. Penelitian ini mengukur sistem pengendalian internal (SPI) dengan beberapa aspek pengendalian internal pemerintahaan, dimana tertuang dalam Peraturan Pemerintah (PP) No 60 tahun 2008 yang dikaji dalam 14 pertanyaan yang diyakini memiliki pengaruh terhadap akuntabilitas pengelolaan keuangan desa.

Sistem Pengendalian internal diyakini dapat membantu dalam mewujudkan akuntabilitas pengelolaan keuangan desa yang lebih baik dengan adanya fungsi pengawasan dari BPD dan pemerintah daerah serta pemerintah pusat. Dalam penelitian Widyatama et al., (2017); Karyadi (2019); Yesinia et al.,(2018) 
Studi Akuntansi \& Keuangan Indonesia

memberikan bukti bahwa sistem pengendalian internal merupakan suatu faktor yang dapat mewujudkan akuntabilitas pengelolaan keuangan desa yang lebih baik. Berdasarkan penjelasan tersebut, maka hipotesis yang diajukan adalah

\section{H2: Sistem Pengendalian Internal Berpengaruh Positif Terhadap Akuntabilitas Pengelolaan Keuangan Desa di Kecamatan Tanawawo.}

\section{Pengaruh Partisipasi Masyarakat Desa Terhadap Akuntabilitas Pengelolaan Keuangan Desa}

Partisipasi masyarakat desa adalah suatu aspek sensitif, dimana memiliki peranan penting dalam menentukan akuntabilitas pengelolaan keuangan desa. Partisipasi masyakat desa yang semakin aktif dan turut serta dalam pembangunan desa mempu menciptakan pemerintaan desa yang merata dan adil. Luthfiani et al., (2020) menjelaskan bahwa partisipasi masyakat adalah sebuah keterlibatan masyarakat desa pada umumnya dalam pengidentifikasian isu-isu serta potensi pada lingkup desa, mencari solusi secara musyawarah dan kekeluargaan terkait upaya dari isu-isu tersebut, serta upaya untuk mengatasi masalah tersebut. Demi mewujudkan pemerintahaan yang baik, maka harus tertuju pada segala indikator seperti pemerataan dan pembangunan masyarakat desa yang lebih partisipatif. Masyarakat desa yang partisipastif merupakan sebuah indikator penting yang diyakini mampu meningkatkan pengembangan desa yang semakin maju dan merata dalam segala aspek kognitif lainnya. Anggaran dana desa yang semakin besar tiap tahunnya tentunya tidak memiliki nilai apa-apa jika tidak adanya kerjasama dari elemen masyarakat desa pada umumnya. Elemen desa diharapkan lebih memiliki rasa persaudaraan dan nasionalisme yang lebih tinggi untuk bersama-sama memajukan desa dengan meningkatakan budaya partisipatif masyarakat desa serta elemen desa seluruhnya. Keikutsertaan seluruh komponen desa seluruhnya merupakan salah satu kunci penting pemerataan partisipatif desa yang lebih baik.

Pada dasarnya pemerataan pembangunan desa merupakan suatu indikator penting yang mampu menghasilkan masyarakat Indonesia yang lebih sejahtera, yang dimulai dari tingkatan pemerintaan terkecil tersebut guna memperkokoh landasan pembangunan nasional. Strategi pemerintah dalam pembangunan desa tentunya berkaitan dengan pemerataan dan peningkatan dari sisi pelayanaan administrasi dan juga taraf hidup masyarakat desa pada umunya. Suatu pembangunan masyarakat desa yang adil dan merata tentunya terdiri dari tiga komponen penting yaitu masyakat, aparat desa dan pemerintah. Kesadaran masyarakat tentang pentingnya keikutsertaan dalam sebuah program desa juga merupakan sebuah harapan besar dalam pewujudan pemerataan tersebut. Strategi yang harus diterapkan oleh masyarakat desa adalah terkait pentingnya kesadaran dari masyarakat desa sendiri untuk secara bersama-sama dengan aparatur desa untuk membangun desa. Untuk berhasilnya program tersebut warga masyarakat dituntut untuk terlibat tidak hanya dalam aspek kognitif dan praktis tetapi juga keterlibatan emosional. Penelitian ini mengukur partisipasi masyarakat dari beberapa aspek seperti keterlibatan masyarakat desa, keikutsertaan masyarakat desa dalam penyusunan dan perencanaan anggaran desa serta melakukan penilaian dan pengawasan dari kinerja aparatur pengelola keuangan desa yang diyakini memiliki pengaruh terhadap akuntabiitas pengelolaan keuangan desa.

Partisipasi masyarakat dalam penelitian ini adalah terkait keterlibatan dan atau keikutsertaan masyarakat secara sadar dalam proses pembangunan dalam rangka mencapai pemerataan desa dari sisi partisipatif yang lebih baik. Hubungan agency theory dengan penelitian ini yaitu masyarakat sebagai principal memberikan kepercayaan kepada pemerintah sebagai agent dalam pengelolaan keuangan desa. Masyarakat yang secara aktif dan adaptis diikutsertakan dalam pengambilan keputusan pemerintah desa diyakini dapat membantu memberikan sumbangsih dalam kaitannya dengan mewujudkan akuntabilitas pengelolaan keuangan desa yang lebih baik. Penelitian ini mengukur partisipasi masyarakat yang dikaji dalam 8 pertanyaan kunci yang diyakini memiliki pengaruh terhadap akuntabilitas pengelolaan keuangan desa. Mada et al., (2017) memberikan bukti bahwa partisipasi masyarakat berpengaruh terhadap akuntabilitas pengelolaan keuangan desa. Hal tersebut menjelaskan bahwa akuntabilitas pengelolaan keuangan desa yang baik sangat ditentukan oleh partisipasi masyarakat yang tinggi.

H3: Partisipasi Masyarakat Desa berpengaruh Positif Terhadap Akuntabilitas Pengelolaan Keuangan Desa di Kecamatan Tanawawo.

\section{Pengaruh Penggunaan Aplikasi Siskeudes Terhadap Akuntabilitas Pengelolaan Keuangan Desa}

Di era yang serba modern saat ini serta tuntutan pertanggungjawaban akuntabilitas keuangan desa yang semakin tinggi, aparatur desa selaku agen tentunya memerlukan sebuah alat atau sistem yang dapat membantu dalam rangkaian pekerjaan aparatur desa. Berdasarkan latar belakang tersebut, BPKP menciptakan sebuah 
Studi Akuntansi \& Keuangan Indonesia

sistem berupa aplikasi yang diyakini dapat membantu pengelolaan dana desa yaitu aplikasi Siskeudes. Hubungan antara agency theory dengan aplikasi Sikeudes, dapat dilihat dari sisi akuntabilitas pengelolaan keuangan desa, dimana dengan adanya aplikasi Siskeudes, agen diwajibkan untuk mampu menyajikan laporan keuangan desa yang sesuai dengan standar akuntabilitas pengelolaan keuangan desa. Hal tersebut juga diyakini mampu meminimalisir adanya asimetris informasi antara agen dan prinsipal. Aplikasi Sikeudes diyakini dapat meningkatkan akuntabilitas pengelolaan keuangan desa dimana dengan adanya penerapan dan penggunaan aplikasi keuangan ini, aparatur pengelola keuangan desa dapat sedikit terbantu untuk memberikan pelaporan keuangan yang benar dan sesuai dengan ketentuan UU yang berlaku. Selain itu aplikasi Siskeudes juga memberikan efektif dan efisiensi dari segi penerapan dan pertanggungjawaban.

Di zaman yang serba modern saat ini, pengembangan aplikasi keuangan merupakan sebuah hal yang harus dilakukan oleh organisasi maupun perusahaan publik untuk memperbaiki kualitas tata kelola pemerintah desa yang lebih berkualitas, efektif serta efisiensi dalam pengelolaannya. Pemerintah pusat dalam hal ini Badan Pengawasan Keuangan Pemerintahaan (BPKP) bekerjasama dengan kementerian dalam negeri pada tahun 2015 mengembangkan suatu aplikasi yang kini disebut sebagai Sistem Keuangan Desa (Siskeudes) sebagai suatu sarana yang digunakan oleh aparat desa dalam kaitanya dengan akuntabilitas pengelolaan keuangan desa dari sisi pelaporannya. BPKP juga menegaskan bahwa aplikasi Siskeudes ini telah sesuai dengan regulasi yang berlaku untuk memudahkan tata kelola keuangan desa, sangat mudah untuk dalam penggunaan aplikasinya, dilengkapi dengan sistem pengendalian internal (Built-in Internal Control), serta didukung dengan petunjuk pelaksanaan implementasi dan manual aplikasi yang mengacu pada peraturan pengelolaan keuangan desa yang diatur dalam Permendagri Nomor 113 Tahun 2014 tentang Pengelolaan Keuangan Desa. Aplikasi Siskeudes ini menggunakan database microsoft acces sehingga lebih memudahkan penerapan oleh pengguna aplikasi yang masih awam sekalipun. Penggunaan aplikasi Siskeudes dalam penelitian ini diukur dengan 8 pertanyaan yang diyakini dapat mengukur pemanfaatan penggunaan aplikasi Siskeudes di kecamatan Tanawawo.

Gayatri dan Latrini (2018) dan Luthfiani et al., (2020) membuktikan bahwa penggunaan aplikasi Sikeudes berpengaruh positif terhadap pengelolaan keuangan desa.

Berdasarkan penjelasan tersebut, maka hipotesis yang diajukan adalah:

H4: Penggunaan Aplikasi Siskeudes Berpengaruh Positif Terhadap Akuntabilitas Pengelolaan Keuangan Desa di Kecamatan Tanawawo.

\section{Kerangka Pemikiran}

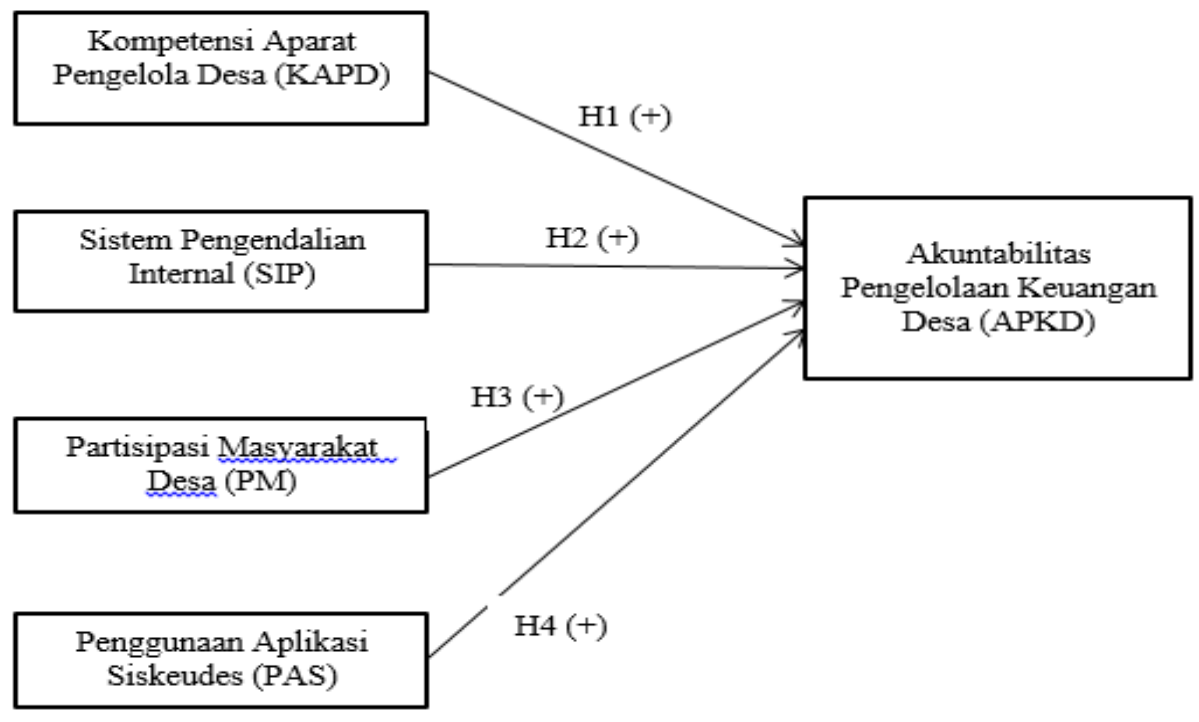

Gambar 1. Kerangka Penelitian 


\section{Metode Penelitian}

\section{Populasi dan Sampel}

Penelitian ini direncanakan menggunakan populasi pada seluruh aparatur desa di wilayah Kecamatan Tanawawo, Kabupaten Sikka, Nusa Tenggara Timur yang berjumlah kurang lebih 88 orang. Sampel pada penelitian ini yaitu Kepala Desa, Sekretaris Desa, Kepala urusan Tata Usaha, Kepala urusan Keuangan, Kepala urusan Perencanaan, Kepala seksi Pemerintahan, Kepala seksi Perencanaan, Kepala seksi Pelayanan dan Badan Pengawas Desa (BPD) di setiap desa yang berada di wilayah Kecamatan Tanawawo. Teknik pengambilan sampel dalam penelitian ini adalah dengan menggunakan convenience sampling dimana pengambilan sampel pada penelitian ini didasarkan pada ketersediaan elemen dan kemudahan untuk memperoleh data tersebut.

Penelitian ini menggunakan desain dengan pendekatan kuantitatif, dimana pengujian hipotesis. Penelitian ini bertujuan untuk menguji hipotesis terkait pengaruh kompetensi aparat pengelola desa, sistem pengendalian internal, partisipasi masyakarat desa dan penggunaan aplikasi sistem keuangan desa terhadap akuntabilitas pengelolaan keuangan desa di wilayah Kecamatan Tanawawo.

Jenis data yang digunakan dalam penelitian ini merupakan data primer. Dimana data primer berkaitan dengan perolehan data penelitian yang diperoleh secara langsung ditempat penelitian yang digunakan peneliti. Penyebaran kuesioner yang dilakukan secara langsung kepada seluruh elemen pemerintah desa merupakan bentuk dari data primer yang digunakan oleh peneliti. Kuesioner yang digunakan pada penelitian ini adalah dengan menggunakan kuesioner yang terdiri dari empat variabel independen dan satu variabel dependen.

Adapun metode pengumpulan data dalam penelitian ini yaitu dengan menggunakan kuesioner dengan tujuan memperoleh data yang relevan, dapat dipercaya, obyektif dan dapat dijadikan landasan dalam proses analisis terkait variabel yang diteliti. Penyebaran kuesioner dilakukan secara langsung kepada aparatur desa di wilayah Kecamatan Tanawawo dengan estimasi waktu dua minggu. Selain itu, penulis juga melakukan interview singkat kepada aparatur desa dan masyarakat desa terkait variabel-variabel penelitian yang diyakini memiliki pengaruh terhadap akuntabilitas pengelolaan keuangan desa di Kecamatan Tanawawo. Interview kepada aparatur desa dan masyarakat perlu dilakukan untuk mendapatkan penjelasan lanjutan dari kuesioner yang telah dibagi kepada para responden. Analisis data yang digunakan dalam penelitian ini menggunakan regresi linier berganda, dimana dalam uji regresi tersebut akan diuji pengaruh antara kompetensi aparat pengelola desa, sistem pengendalian internal, partisipasi masyarakat desa dan penggunaan aplikasi Siskeudes terhadap akuntabilitas pengelolaan keuangan desa dengan menggunakan aplikasi Statistical Product and Service Solutions (SPSS) edisi 23.

\section{Operasionalisasi Variabel}

Variabel Kompetensi Aparat Pengelola Desa (KAPD) dalam penelitian ini di ukur dengan 3 komponen dasar yang diyakini dapat mewakili variabel kompetensi aparat pengelola desa yaitu pengetahuan (knowladge), keahlian (skills), dan kemampuan (abilities) yang dimiliki oleh seorang individu yang tersebar dalam 6 butir pertanyaan. Analisis data yang digunakan dalam mengukur variabel KAPD yaitu dengan menggunakan kuisoner yang disebarkan kepada aparatur desa di Kecamatan Tanawawo.

Variabel Sistem Pengendalian Internal (SPI) dalam penelitian ini di ukur dengan 5 komponen dasar SPI yaitu lingkungan pengendalian, penilaian resiko, kegiatan pengendalian, informasi dan komunikasi dan pemantauan pengendalian internal yang tersebar dalam 14 butir pertanyaan. Analisis data yang digunakan dalam mengukur variabel SPI yaitu dengan menggunakan kuisoner yang disebarkan kepada aparatur desa di Kecamatan Tanawawo.

Variabel Partisipasi Masyarakat (PM) dalam penelitian ini di ukur dengan 3 komponen dasar PM yaitu pendekatan partisipatif, pendekatan kemandirian dan pendekatan keterpaduan yang tersebar dalam 8 butir pertanyaan yang diyakini dapat menjelaskan keterkaitan antara partisipasi masyarakat dalam penelitian. Analisis data yang digunakan dalam mengukur variabel PM yaitu dengan menggunakan kuisoner yang disebarkan kepada aparatur desa di Kecamatan Tanawawo.

Variabel Penggunaan Aplikasi Siskeudes (PAS) dalam penelitian ini di ukur dengan 2 komponen dasar PAS yaitu efesiensi pemanfaatn aplikasi siskeudes dan efektifitas penggunaan aplikasi dan jaringan, dimana hal tersebut juga berhubungan dengan ketersediaan akses jaringan yang tersebar dalam 8 butir pertanyaan. 
Studi Akuntansi \& Keuangan Indonesia

Analisis data yang digunakan dalam mengukur variabel PAS yaitu dengan menggunakan kuisoner yang disebarkan kepada aparatur desa di Kecamatan Tanawawo.

Adapun rumus regresi dirumuskan sebagai berikut $\mathrm{Y}=\mathrm{B}_{0}+\mathrm{B}_{1} \mathrm{KAPD}+\mathrm{B}_{2} \mathrm{SPI}+\mathrm{B}_{3} \mathrm{PMD}+\mathrm{B}_{4} \mathrm{PAS}+\mathrm{e}$

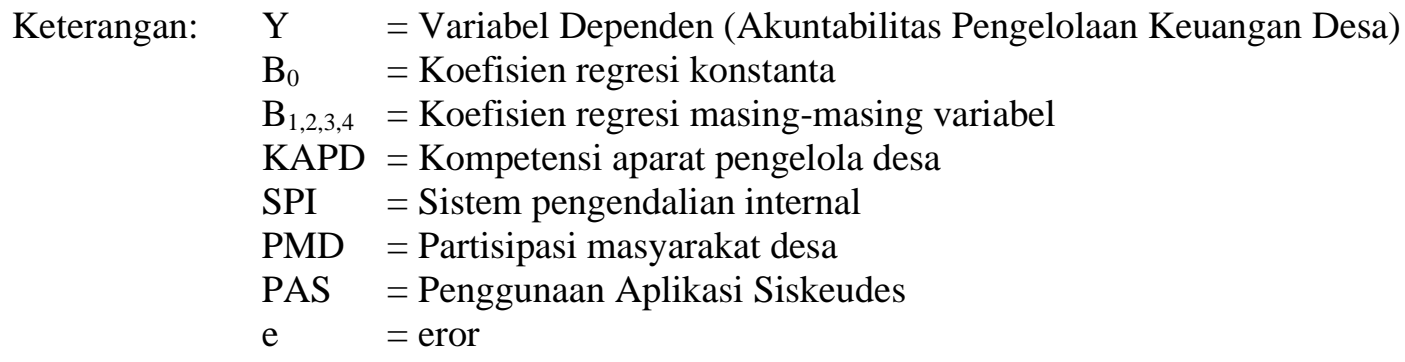

\section{Hasil dan Diskusi}

\section{Hasil Penelitian}

\section{Pilot Test/ Feedback Responden}

Sebelum kuesioner penelitian disebarkan kepada responden, dilakukan pilot test atau tes uji coba terlebih dahulu kepada 10\% dari target jumlah sampel yang terkumpul yaitu 8 orang responden, yang terdiri dari 1 orang Camat, 1 orang Sekretaris Camat, 1 orang mantan Kepala Desa, dan 5 orang aparatur Desa Bu Watuweti yang merupakan salah satu desa di Kecamatan Tanawawo sehingga total sampel yang digunakan dalam pilot test adalah 8 orang. Uji pilot test di bagian ini juga menerima masukan berupa feedback kuesioner dari responden terkait pertanyaan yang diberikan oleh penulis. Adapun pemberian feedback tersebut agar item-item pertanyaan yang terdapat pada variabel-variabel tersebut sesuai dengan ketentuan UU yang berlaku dan dapat dipahami dengan bahasa yang sederhana dan mudah dimengerti oleh responden nantinya.

\section{Uji Validitas}

Uji validitas merupakan suatu pengukuran yang dilakukan untuk melihat apakah suatu kuesioner dalam penelitian layak atau tidak untuk digunakan. Suatu kuesioner akan dikatakan valid apabila pertanyaan pada kuisioner mampu untuk mengungkapkan sesuatu yang akan diukur oleh kuesioner tersebut (Ghozali, 2016). Setiap butir pernyataan pada kuesioner dapat dikatakan valid apabila nilai signifikansinya $\leq 0,05$ dan dikatakan tidak valid apabila nilai signifikansinya $\geq 0,05$.

Berdasarkan tabel 10 (Terlampir), dapat disimpulkan bahwa dari semua variabel penelitian yaitu Kompetensi Aparat Pengelola Desa (KAPD), Sistem pengendalian internal (SPI), Partisipasi Masyarakat Desa (PMD), Penggunaan Aplikasi Siskeudes (PAS) dan Akuntabilitas Pengelolaan Keuangan Desa (AKPD) terlihat bahwa seluruh nilai signifikan. Pada tiap butir pertanyaan tersebut kurang dari 0,005 yaitu 0,000, sehingga dapat disimpulkan bahwa semua data yang didapat merupakan data yangvalid.

\section{Uji Reliabilitas}

Uji Reliabilitas merupakan suatu pengukuran yang dilakukan untuk melihat indikator dalam suatu varaibel atau kontraks. Uji reliabilitas perlu dilakukan dalam penelitian ini untuk menilai konsistensi responden pada saat mengisi kuesioner yang dibagikan. 
Tabel 1. Uji Reliabilitas

\begin{tabular}{ccc}
\hline Indikator Variabel & Cronbach's Alpha & Reliabel/Tidak Reliabel \\
\hline Akuntabilitas Pengelolaan & 0,739 & Reliabel \\
Keuangan Desa (AKPD) & & Reliabel \\
Kompetensi Aparat Pengelola Desa & 0,730 & \\
(AKPD) & & Reliabel \\
Sistem Pengendalian Internal (SPI) & 0,731 & Reliabel \\
Partsipasi Masyarakat Desa (PMD) & 0,678 & Reliabel \\
Aplikasi Penggunaan Siskeudes & 0,750 & \\
(PAS) & & \\
\hline
\end{tabular}

Sumber: Data diolah (2020)

Berikut hasil uji reliabilitas pada penelitian ini yang dapat dilihat pada tabel 1. Hasil uji statistik Cronbach's Alpha dimana variabel Akuntabilitas Pengelolaan Keuangan Desa (AKPD) menunjukkan nilai 0,739 (73\%), variabel Kompetensi Aparat Pengelola Desa (KAPD) menunjukan nilai 0,730 (73\%), variabel Sistem Pengendalian Internal (SPI) menunjukan nilai 0,731 (73\%), variabel Partisipasi Masyarakat Desa (PMD) menunjukan nilai 0,678 (67\%) dan variabel Penggunaan Aplikasi Siskeudes menunjukkan nilai 0,750 (75\%). Berdasarkan hasil diatas, maka disimpulkan bahwa varaibel yang digunakan dalam penelitian ini reliabel dengan presentasi diatas $60 \%$.

\section{Gambaran Profil Responden}

a. Jabatan

Berdasarkan data yang terdapat di dalam tabel 2, maka dapat disimpulkan bahwa responden yang menjabat sebagai Kepala Desa berjumlah 8 orang $(9,1 \%)$, responden yang menjabat sebagai Sekretaris Desa berjumlah 8 orang $(9,1 \%)$, responden yang menjabat sebagai Kaur TU berjumlah 8 orang $(9,1 \%)$, responden yang menjabat sebagai Kaur Keuangan berjumlah 8 orang $(9,1 \%)$, responden yang menjabat sebagai Kasie Pemerintahan berjumlah 8 orang $(9,1 \%)$, responden yang menjabat sebagai Kasie Kesejahterahan berjumlah 8 orang $(9,1 \%)$, responden yang menjabat sebagai Kasie Pelayanan berjumlah 8 orang $(9,1 \%)$, responden yang menjabat sebagai Kepala Dusun berjumlah 24 orang $(27,3 \%)$ dan responden yang menjabat sebagai Kepala Desa berjumlah 8 orang $(9,1 \%)$. Dari hasil perhitungan data diatas bahwa jumlah kepala Dusun paling banyak dibandingkan aparatur desa lain dikarenakan satu desa terdiri atas 3 kepala dusun.

Tabel 2. Profil Responden Berdasarkan Jabatan

\begin{tabular}{ccc}
\hline Jabatan & Jumlah & Presentasi \\
\hline Kepala Desa & 8 & $9,1 \%$ \\
Sekretaris Desa & 8 & $9,1 \%$ \\
Kaur TU & 8 & $9,1 \%$ \\
Kaur Keuangan & 8 & $9,1 \%$ \\
Kasie Pemerintahaan & 8 & $9,1 \%$ \\
Kasie Kesejahteraan & 8 & $9,1 \%$ \\
Kasie Pelayanan & 8 & $9,1 \%$ \\
Kepala Dusun & 24 & $27,3 \%$ \\
BPD & 8 & $9,1 \%$ \\
TOTAL & 88 & $100 \%$
\end{tabular}

Sumber: Data diolah (2020) 
Studi Akuntansi \& Keuangan Indonesia

b. Jenis Kelamin

Berdasarkan data yang terdapat di dalam tabel 3, maka dapat diketahui bahwa apartur desa dengan jenis kelamin perempuan 16 orang $(18,2 \%)$ sedangkan reponden dengan jenis kelamin laki-laki berjumlah 72 orang $(81,8 \%)$. Dari hasil perhitungan diatas, maka dapat disimpulkan bahwa mayoritas responden berjenis kelamin laki-laki.

Tabel 3. Profil Responden Berdasarkan Jenis Kelamin

\begin{tabular}{ccc}
\hline Jenis Kelamin & Jumlah & Presentase \\
\hline Laki-Laki & 72 & $81,8 \%$ \\
Perempuan & 16 & $18,2 \%$ \\
Jumlah & 88 & $100 \%$ \\
\hline
\end{tabular}

Sumber : Data diolah (2020)

c. Usia

Berdasarkan data yang terdapat di dalam tabel 4, maka dapat diketahui bahwa aparatur desa di Kecamatan Tanawawo yang berusia 20-30 tahun berjumlah 13 orang $(14,8 \%)$, aparatur desa di Kecamatan Tanawawo yang berusia 31-40 tahun berjumlah 7 orang $(8,0 \%)$, aparatur desa di Kecamatan Tanawawo yang berusia 41-50 tahun berjumlah 39 orang (44,3\%), aparatur desa di Kecamatan Tanawawo yang berusia 51 tahun keatas berjumlah 7 orang $(8,0 \%)$. Berdasarkan tabel tersebut dapat disimpulkan bahwa mayoritas usia aparatur desa yang berada di wilayah Kecamatan Tanawawo adalah berusia 41-50 tahun.

Tabel 4. Profil Responden Berdasarkan Usia

\begin{tabular}{ccc}
\hline Usia & Jumlah & Presentase \\
\hline $20-30$ Tahun & 13 & $14,8 \%$ \\
$31-40$ Tahun & 7 & $8,0 \%$ \\
41-50 Tahun & 39 & $44,3 \%$ \\
51 Tahun keatas & 29 & $33,0 \%$ \\
Jumlah & 88 & $100 \%$ \\
\hline
\end{tabular}

Sumber: Data diolah (2020)

d. Masa Kerja

Berdasarkan data yang terdapat dalam tabel 5, maka dapat diketahui bahwa aparatur desa yang memiliki masa kerja 0-5 tahun berjumlah 61 orang $(69,3 \%)$, reponden dengan masa kerja 6-10 tahun berjumlah 20 orang (22,7\%), reponden dengan masa kerja 11-15 tahun berjumlah 2 orang $(2,3 \%)$ dan reponden dengan masa kerja paling lama yakni lebih dari 15 tahun berjumlah 5 orang $(5,7 \%)$. Mengacu pada uraian tersebut, maka diketahui bahwa mayoritas masa kerja aparatur desa pada wilayah Kecamatan Tanawawo yaitu selama 0-5 tahun yang berjumlah 61 orang. Hal tersebut menyimpulkan bahwa, ratarata pemerintah desa yang bekerja di Kecamatan Tanawawo merupakan orang-orang yang saat ini sudah bekerja di selama 0-5 tahun.

\begin{tabular}{ccc} 
& Tabel 5. Profil Responden Berdasarkan Usia \\
\hline Masa Kerja & Jumlah & Presentase \\
\hline $0-5$ Tahun & 61 & $69,3 \%$ \\
$6-10$ Tahun & 20 & $22,7 \%$ \\
$11-15$ Tahun & 2 & $2,3 \%$ \\
15 Tahun keatas & 5 & $5,7 \%$ \\
Jumlah & 88 & $100 \%$ \\
\hline
\end{tabular}

Sumber : Data diolah (2020) 
Studi Akuntansi \& Keuangan Indonesia

e. Pendidikan Terakhir

Berdasarkan data yang terdapat di dalam tabel 6, maka dapat diketahui bahwa aparatur desa dengan tingkat pendidikan akhir lulusan SMA/sederajat berjumlah 72 orang $(81,8 \%)$, responden dengan tingkat pendidikan diploma berjumlah 1 orang $(1,1 \%)$, responden dengan tingkat pendidikan S1 berjumlah 15 orang $(17,0 \%)$, dan responden dengan tingkat pendidikan S2 berjumlah 0 orang $(0 \%)$. Berdsarkan data tersebut, maka diketahui bahwa tingkat pendidikan aparatur desa di wilayah kecamatan tanawawo dalam penelitian ini didominasi oleh responden dengan latar belakang pendidikan akhir SLTA/sederajat.

Tabel 6. Profil Responden Berdasarkan Usia

\begin{tabular}{ccc}
\hline Pendidikan & Jumlah & Presentase \\
\hline SMA & 72 & $81,8 \%$ \\
Diploma & 1 & $1,1 \%$ \\
S1 & 15 & $17,0 \%$ \\
S2 & 0 & $0 \%$ \\
Jumlah & 88 & $100 \%$ \\
\hline
\end{tabular}

Sumber : Data diolah (2020)

\section{Statistik Deskriptif}

Pengujian ini dilakukan untuk menjabarkan secara lebih rinci terkait deskripsi dari hasil jawaban responden untuk setiap variabel independen maupun dependen dalam penelitian ini. Deskripsi dari jawaban responden menggunakan perhitungan nilai rata-rata (mean) dan standar deviasi (standard deviation) jawaban untuk setiap pernyataan yang termuat di dalam kuesioner penelitian.

Tabel 7. Hasil Uji Statistik Deskriptif

\begin{tabular}{cccccc}
\hline & N & Minimum & Maximum & Mean & Std. Deviation \\
\hline KAPD & 88 & 3,17 & 5,00 & 4,254 & 0,5231 \\
SPI & 88 & 3,29 & 5,00 & 4,236 & 0,5088 \\
PM & 88 & 3,75 & 5,00 & 4,217 & 0,4168 \\
PAS & 88 & 3,25 & 5,00 & 4,250 & 0,5337 \\
AKPD & 88 & 3,50 & 5,00 & 4,237 & 0,5401 \\
\hline Total N & 88 & & &
\end{tabular}

Sumber: Data diolah (2020)

Berdasarkan pengujian tersebut dapat disimpulkan bahwa keseluruhan responden rata-rata menjawab diangka 4 atau setuju dengan pertanyaan yang diberikan terkait variabel-variabel yang ditanyakan. Sedangkan nilai terendah adalah 3 dan nilai tertinggi ada 5 dari skala 1-5.

Selanjutnya, model telah melewati uji asumsi klasik yang meliputi uji normalitas, uji multikolinearitas, dan uji heteroskedastisitas. Selain itu, model juga telah melewati uji kelyakan model yang terdiri dari uji koefisien determinasi $\left(\mathrm{R}^{2}\right)$ dan uji statistic $\mathrm{F}$.

\section{Uji Hipotesis}

Uji statistik dalam penelitian ini digunakan untuk menguji pengaruh dari setiap variabel independen yaitu kompetensi aparat pengelola desa (KAPD), sistem pengendalian internal (SPI), partisipasi masyarakat desa (PMD), penggunaan aplikasi Siskeudes terhadap variabel dependen yaitu akuntabilitas pengelolaan keuangan desa (AKPD). Adapun hasil uji statistik t dalam penelitian ini adalah sebagai berikut: 
Tabel 8. Uji Hipotesis

\begin{tabular}{cccc}
\hline Variabel & T & Sig & Keterangan \\
\hline KAPD & 10,404 & $0,000^{* * *}$ & H1 Diterima \\
SPI & 2,530 & $0,013^{* *}$ & H2 Diterima \\
PMD & $-0,311$ & 0,756 & H3 Ditolak \\
PAS & 1,443 & 0,153 & H4 Ditolak \\
\hline Adjusted $R^{2}$ & & 0,895 & \\
\hline
\end{tabular}

Sumber: Data diolah (2020)

Keterangan: $* * *, * *, *$ mewakili alpha $1 \%, 5 \%$, dan $10 \%$

Berdasarkan tabel 8 diatas, dapat disimpulkan bahwa variabel KAPD memiliki nilai signifikansi sebesar 0,000, dimana kurang dari 0,05 sehingga dapat disimpulkan variabel KAPD berpengaruh positif terhadap akuntabilitas pengelolaan keuangan desa sehingga hipotesis pertama diterima. Variabel SPI memiliki nilai signifikansi sebesar 0,013 atau kurang dari 0,05 sehingga dapat disimpulkan bahwa variabel SPI berpengaruh positif terhadap akuntabilitas pengelolaan keuangan desa sehingga hipotesis kedua diterima. Variabel PMD memiliki nilai signifikansi sebesar 0,756 atau lebih dari 0,05 sehingga dapat disimpulkan bahwa variabel PMD tidak berpengaruh terhadap akuntabilitas pengelolaan keuangan desa sehingga hipotesis ketiga ditolak. Variabel PAS memiliki nilai signifikansi sebesar 0,153 atau lebih besar dari 0,05 sehingga dapat disimpulkan variabel PAS tidak berpengaruh terhadap akuntabilitas pengelolaan keuangan desa sehingga hipotesis keempat ditolak.

\section{Diskusi}

\section{Pengaruh Kompetensi Aparat Pengelolah Desa terhadap Akuntabilitas Pengelolaan Keuangan Desa}

Berdasarkan hasil uji hipotesis atau uji yang telah dilakukan terkait variabel tersebut diperoleh hasil bahwa kompetensi aparat pengelola desa berpengaruh positif terhadap akuntabilitas pengelolaan keuangan desa di wilayah Kecamatan Tanawawo sehingga dapat disimpulkan bahwa hipotesis yang telah diajukan diterima. Hal ini memberikan bukti bahwa kompetensi aparat pengelola desa yang semakin baik dalam kaitanya dengan pengalaman, pengetahuan dan pendidikan aparatur desa secara langsung mempengaruhi akuntabilitas pengelolaan keuangan desa di Kecamatan Tanawawo. Hasil penelitian ini mengkonfirmasi agency theory dalam penelitian ini, dimana kompetensi aparat pengelola desa yang semakin baik dan kompeten akan mampu menjadi landasan bagi agent dalam meminimalisir adanya asimetris informasi yang terjadi antara agent dan principal dalam kaitannya dengan pelaporan maupun penyajian akuntabilitas pengelolaan keuangan desa. Aparat desa yang semakin kompeten juga dapat menjadi pedoman dan dasar dalam menjalankan fungsi serta tanggung jawabnya dalam akuntabilitas pengelolaan keuangan desa. Adapun penelitian ini sesuai dengan penelitian yang dilakukan oleh Mada et al., (2017); Karyadi (2019); Luthfiani et al., (2020) yang memberikan bukti bahwa kompetensi merupakan suatu faktor yang dapat mewujudkan akuntabilitas pengelolaan keuangan desa yang lebih baik. Sweetania et al., (2019) menjelaskan bahwa kompetensi merujuk kepada pengetahuan, kealihan dan kemampuan yang dilakukan dengan standar tertentu. Kompetensi aparat pengelola desa di wilayah Kecamatan Tanawawo dapat dikatakan sudah cukup baik diterapkan di wilayah kecamatan ini.

Dari segi pendidikan, aparatur desa di wilayah kecamatan ini harus memiliki kualifikasi pendidikan minimal SMA atau sesuai dengan Peraturan Menteri Dalam Negeri (Permendagri) No 83 Tahun 2015 pasal 2 yang mengisyaratkan bahwa aparatur desa yang ingin menjadi aparatur desa memiliki kualifikasi paling rendah sekolah menengah umum atau yang sederajat. Dari segi pelatihan, aparatur desa di wilayah Kecamatan Tanawawo sudah cukup sering dibekali dengan beberapa pelatihan yang secara berangsur dilakukan dan diadakan oleh pemerintah Kabupaten Sikka maupun pemerintah Provinsi NTT seperti penguatan organisasi desa, pembekalan dan sosialisasi penguatan fungsi aparatur desa dan sosialisasi penunjang lain dalam kaitanya dengan peningkatan kompetensi aparatur desa di wilayah kecamatan ini. Pelatihan yang terus menerus dilakukan oleh pemerintah diyakini dapat menjadi salah satu bekal bagi aparatur desa dalam mengelola keuangan desa baik dari sisi akuntabilitas mapun transparansi. Pelatihan terkait penunjang kompetensi aparatur desa juga telah dilakukan secara merata di wilayah kecamatan ini secara berkala. Pelatihan dalam kaitanya dengan menunjang kompetensi aparat desa juga merupakan salah satu program dari 
Studi Akuntansi \& Keuangan Indonesia

desa yang telah dianggarkan untuk menguatkan dan menunjang kapasitas pekerjaan dari aparatur desa itu sendiri.

Berdasarkan penjelasan tersebut, dapat disimpulkan bahwa kompetensi aparatur pengelolaan desa di wilayah Kecamatan Tanawawo dari segi pendidikan, pelatihan dan keahlian sudah dijalankan dengan cukup baik. Ketika seorang aparatur desa memiliki kompetensi yang baik, maka akan berguna dalam menunjang kapasitas seorang pemimpin dalam menjalankan fungsi organisasi dan mendukung fungsi pertanggung jawaban atau akuntabilitas dalam pengelolaan keuangan desa.

\section{Pengaruh Sistem Pengendalian Internal Terhadap Akuntabilitas Pengelolaan Keuangan Desa}

Berdasarkan hasil pengujian hipotesis yang telah dilakukan terkait variabel tersebut diperoleh hasil bahwa sistem pengendalian internal berpengaruh positif terhadap akuntabilitas pengelolaan keuangan desa di wilayah Kecamatan Tanawawo sehingga dapat disimpulkan bahwa hipotesis yang telah diajukan diterima. Hal ini memberikan bukti bahwa sistem pengendalian internal yang semakin baik dalam kaitannya dengan komponen-komponen (5 komponen) SPI terhadap pengendalian internal telah dijalankan dengan baik. Hasil penelitian ini mengkonfirmasi agency theory dalam penelitian ini, dimana sistem pengendalian internal yang semakin baik dapat digunakan sebagai fungsi controlling yang dapat mengawal kepala desa dan aparat desa pada umumnya dalam hal ini agent untuk lebih terarah dalam menyajikan akuntabilitas pengelolaan keuangan desa yang lebih baik. Adapun penelitian ini sesuai dengan penelitian yang dilakukan oleh Widyatama (2017); Karyadi (2019); Yesinia et al., (2018) memberikan bukti bahwa sistem pengendalian internal merupakan suatu faktor yang dapat mewujudkan akuntabilitas pengelolaan keuangan desa yang lebih baik.

Sistem pengendalian internal (SPI) di wilayah Kecamatan Tanawawo telah diterapkan dengan cukup baik di wilayah kecamatan ini. Pemerintah desa diwilayah kecamatan ini dari segi lingkungan pengendalian lingkungan pengendalian telah sesuai dengan situasi desa yang dibuktikan dengan struktur organisasi yang jelas, tugas dan tanggungjawab, komunikasi serta review dari beberapa temuan yang diperoleh. Dari segi penilaian risiko, aparatur desa di wilayah kecamatan ini telah menerapkan perilaku dan norma yang baik, memberikan keteladanan dalam pelaksanaan peraturan yang berlaku, dan wewenang yang diberikan sesuai tanggungjawab aparat desa. Dari segi kegiatan pengendalian aparatur desa di wilayah kecamatan ini telah efektif dalam lingkup pengendalian pemerintahaan desa, seperti review kinerja aparat pengelola desa, pemisahan fungsi dan juga pengamanan aset desa dalam kaitanya dengan akuntabilitas pengelolaan keuangan desa.

Dari segi informasi dan komunikasi mengimplementasikan penggunaan sistem informasi yang ada dalam kaitannya dengan mendukung akuntabilitas pengelolaan keuangan desa yang lebih baik dan dari segi pemantauan pengendalian internal evaluasi secara berkala terkait kelebihan dan kelemahan sistem pengendalian internal pemerintah desa serta rekomendasi untuk memperbaiki serta terkait fungsi dari Badan Pengawasan Desa dalam mengontrol keseluruhan evaluasi tersebut. Berdasarkan penjelasan tersebut, dapat disimpulkan bahwa sistem pengendalian internal di wilayah Kecamatan Tanawawo dari kelima komponen penilaian sudah dijalankan dan diterapkan dengan cukup baik. Ketika sistem pengendalian internal dalam suatu wilayah telah dilaksanakan dengan baik, maka akan berguna dalam menunjang fungsi pertanggungjawaban aparatur desa dan dapat meminimalisir adanya kecurangan dan penggelapan dana desa

\section{Pengaruh Partisipasi Masyarakat Desa Terhadap Akuntabilitas Pengelolaan Keuangan Desa}

Berdasarkan hasil pengujian hipotesis yang telah dilakukan terkait variabel tersebut diperoleh hasil bahwa partisipasi masyarakat desa tidak memiliki pengaruh terhadap akuntabilitas pengelolaan keuangan desa di wilayah kecamatan Tanawawo sehingga dapat disimpulkan bahwa hipotesis yang telah diajukan ditolak. Hal ini memberikan bukti bahwa partisipasi masyarakat desa tidak memiliki pengaruh terhadap akuntabilitas pengelolaan keuangan desa di wilayah Kecamatan Tanawawo. Hasil penelitian ini tidak mengkonfirmasi agency theory, dimana masyarakat yang seharusnya merupakan pihak principal yang bertugas mengawasi kinerja aparatur desa tidak menjalankan fungsi control tersebut sebagaimana mestinya. Tidak adanya partisipasi masyarakat desa secara merata yang diikutsertakan dalam wilayah kecamataan ini juga menyebabkan masyarakat yang sebelumnya diharapkan mampu mengkawal segala proses akuntabilitas pengelolaan keuangan desa menjadi terhambat dikarenakan akses yang diberikan oleh pemerintah desa yang masih sangat terbatas.

Adapun penelitian ini sesuai dengan penelitian yang dilakukan oleh Luthfiani et al., (2020) yang memberikan bukti bahwa partisipasi masyarakat tidak berpengaruh terhadap akuntabilitas pengelolaan 
Studi Akuntansi \& Keuangan Indonesia

keuangan desa. Hasil penelitian ini menunjukkan bahwa partisipasi masyarakat yang tinggi bukan merupakan suatu jaminan terhadap akuntabilitas pengelolaan keuangan desa. Ada atau tidaknya partisipasi masyarakat tidak mempengaruhi akuntabilitas pengelolaan keuangan desa. Partisipasi masyarakat desa di wilayah Kecamatan Tanawawo belum sepenuhnya mewakili masyarakat.

Berdasarkan beberapa interview yang dilakukan oleh penulis terkait partisipasi masyarakat di beberapa desa di wilayah kecamatan ini, dapat disimpulkan bahwa partisipasi masyarakat desa belum sepenuhnya terwakili oleh semua masyarakat desa. Hal ini dikarenakan banyak aparatur desa yang masih memilih masyarakat tertentu saja untuk diikutsertakan dalam rapat yang diadakan oleh pemerintah desa. Adanya sistem tebang pilih ini kemudian menyebabkan aspirasi masyarakat yang ada di wilayah Kecamatan Tanawawo belum seutuhnya terwakilkan dan didengarkan oleh aparatur desa pada umumnya. Sistem tebang pilih yang dumaksud adalah kebanyakan apartur desa hanya mengikutsertakan masyarakat yang dianggap mendukung mereka secara langsung, sedangkan masyarakat desa yang berbeda pendapat jarang sekali diikutsertakan, karena dianggap akan menentang kebijakan yang dibuat mereka. Hal tersebut juga secara langsung menyebabkan tidak adanya pemerataan partispasi desa secara utuh sehingga menyebabkan ketimpangan dalam musyawarah desa secara penuh. Berdasarkan penjelasan tersebut, dapat disimpulkan bahwa partisipasi masyarakat desa di wilayah Kecamatan Tanawawo tidak memiliki pengaruh terhadap akuntabilitas pengelolaan keuangan desa.

\section{Pengaruh Penggunaan Aplikasi Siskeudes Terhadap Akuntabilitas Pengelolaan Keuangan Desa}

Berdasarkan hasil pengujian hipotesis yang telah dilakukan terkait variabel tersebut diperoleh hasil bahwa penggunaan aplikasi Siskeudes tidak memiliki pengaruh terhadap akuntabilitas pengelolaan keuangan desa di wilayah Kecamatan Tanawawo sehingga dapat disimpulkan bahwa hiptesis yang telah diajukan ditolak. Hal ini membuktikan bahwa penggunaan aplikasi Siskeudes tidak memiliki pengaruh terhadap akuntabilitas pengelolaan keuangan desa di wilayah Kecamatan Tanawawo. Hasil penelitian ini tidak mengkonfirmasi agency theory dalam penelitian ini. Penggunaan aplikasi Siskeudes yang diharapkan mampu menjadi salah satu media dan jembatan yang dapat digunakan oleh aparatur desa atau agent untuk meminimalisir adanya asimetris informasi, belum mampu diterapkan dan di mengerti oleh masyarakat yang berperan sebagai principal pada umumnya. Hal tersebut dikarenakan masih terbatasnya akses penggunaan aplikasi Siskeudes dalam wilayah kecamatan ini sehingga menyebabkan penggunaan aplikasi siskeudes yang diharapkan dapat menjadi salah satu media yang dapat digunakan agent atau aparatur desa dalam menyajikan akuntabilitas pengelolaan keuangan desa serta meminimalisir adanya kecurangan dana desa menjadi terhambat. Terhambatnya penggunaan aplikasi Siskeudes tersebut juga dikarenakan akses dan topografi desa yang belum bisa menjangkau akses internet secara penuh. Adapun hasil penelitian ini sesuai dengan penelitian yang dilakukan oleh Karyadi (2019) yang memberikan bukti bahwa sistem teknologi informasi tidak berpengaruh terhadap akuntabilitas pengelolaan keuangan desa. Penggunaan aplikasi Siskeudes yang belum efektif di kecamatan ini merupakan salah satu faktor yang memicu mengapa penggunaan aplikasi Siskeudes di wilayah kecamatan ini tidak berpengaruh terhadap akuntabilitas pengelolaan keuangan desa. Aplikasi Siskeudes di wilayah Kecamatan Tanawawo sendiri telah mulai digunakan pada tahun 2017. Beberapa pelatihan dan seminar untuk keefektifan penggunaan aplikasi ini juga telah dilakukan oleh pemerintah daerah maupun pemerintah pusat. Namun hingga saat ini Kecamatan Tanawawo sendiri belum memiliki bentuk fisik aplikasi siskeudes ini yang ada di kantor desa atau pun kantor kecamatan Tanawawo.

Berdasarkan informasi yang diperoleh penulis dapat diketahui bahwa bentuk fisik Aplikasi Siskeudes hanya berada di kota Maumere yang apabila aparatur desa ingin melakukan pencatatan akuntansi dengan menggunakan aplikasi tersebut harus melakukan perjalanan darat selama kurang lebih 3 jam dengan letak topografi yang susah untuk dijangkau. Letak topografi desa yang masih sangat susah untuk dijangkau oleh listrik merupakan salah satu pemicu kenapa aplikasi ini belum dapat efektif digunakan di kecamatan ini. Kecamatan Tanawawo sendiri telah mengupayakan dengan pemerataan jaringan yang telah disampaikan kepada pemerintah daerah, hal tersebut dilakukan agar dapat megurangi bias dalam pelaksanaan kinerja aparatur desa dalam kaitanya dengan sistem aplikasi maupun kinerja aparat desa pada umumnya. Berdasarkan penjelasan tersebut, dapat disimpulkan bahwa penggunaan aplikasi siskeudes di wilayah Kecamatan Tanawawo tidak memiliki pengaruh terhadap akuntabilitas pengelolaan keuangan desa 


\section{Kesimpulan, Implikasi dan Keterbatasan}

Berdasarkan hasil pengujian yang telah dilakukan dalam penelitian ini, maka simpulan yang dapat diperoleh yaitu: Kompetensi aparat pengelola desa dan sistem pengendalian internal terbukti berpengaruh positif terhadap akuntabilitas pengelolaan keuangan desa di wilayah Kecamatan Tanawawo. Sedangkan partisipasi masyarakat desa dan penggunaan aplikasi Siskeudes terbukti tidak berpengaruh terhadap akuntabilitas pengelolaan keuangan desa di wilayah Kecamatan Tanawawo.

Implikasi dalam penelitian ini secara khusus bagi aparatur desa di wilayah Kecamatan Tanawawo diharapkan dapat memberikan masukan kepada pemerintah kabupaten Sikka terkait efektifitas penggunaan aplikasi siskeudes di wilayah Kecamatan Tanawawo, agar kedepannya aplikasi siskeudes dapat digunakan sepenuhnya di wilayah ini dan dapat mempermudah sistem pembukuan maupun pengeluaran desa. Selain itu aparatur desa juga diharapkan mampu mengikutsertakan masyarakat desa dalam segala pengambilan keputusan terkait kepentingan dan kemajuan desa serta masyarakat pada umumnya.

Keterbatasan dalam penelitian ini terletak pada metode penelitian yang belum secara keseluruhan dapat menggambarkan kondisi rill objek penelitian, sehingga penelitian selanjutnya diharapkan mampu menambahkan metode lain seperti wawancara. Selain itu kondisi daerah penelitian yang sangat sulit dijangkau juga menjadi salah satu keterbatasan dalam penelitian, sehingga menyebabkan peneliti tidak dapat bertemu dengan seluruh komponen desa dan beberapa kuisoner ditetapkan oleh aparat desa yang hadir. Bagi penelitian selanjutnya diharapkan dapat menggunakan atau menambah variabel lain seperti pengawasan, evaluasi kinerja, pajak bendaharawan desa dan variabel bebas lainnya yang diyakini memiliki pengaruh terhadap akuntabilitas pengelolaan keuangan desa guna mendapatkan hasil penelitian yang lebih baik.

\section{Daftar Pustaka}

Gayatri, dan Latrini, M. Y. (2018). Efektivitas Penerapan Sistem Keuangan Desa dan Kualitas Laporan Keuangan Desa.

Jurnal Ilmiah Akuntansi dan Bisnit.13(2): 113-122.

Ghozali, I. 2016. Aplikasi Analisis Multivariete Dengan Program IBM SPSS 23 (Edisi 8)Cetakan ke VIII. Semarang: Badan Penerbit Universitas Diponegoro.

Jensen dan Meckling. (1976). The Theory of The Firm: Managerial Behaviour, Agency Cost, and Ownership Structure. Journal of Financial and Economics , 3: 305-360.

Karyadi, M. (2019). Pengaruh sistem pengendalian intern, pemanfaatan teknologi informasi dan kompetensi sumber daya manusia terhadap akuntabilitas keuangan desa (studi di Kecamatan Aikmel dan Kecamatan Lenek tahun 2018). Journal Ilmiah Rinjani, 7(2), 33-46. https://jurnal.ugr.ac.id/index.php/jir/article/view/123

Kementrian Keuangan. (2017). Buku Saku Dana Desa. Didapat dari https://www.kemenkeu.go.id/apbn2020. (Diakses tanggal 16 juli 2020)

Kementrian Keuangan. (2017). Anggaran Pendapataan dan Belanja Negara (APBN). Didapat dari https://www.kemenkeu.go.id/apbn2020. (Diakses tanggal 16 juli 2020

Luthfiani, B. M., Asmony, T., \& Herwanti, R. . (2020). Analysis of Factors Affecting Accountability in Village Fund Management in Central Lombok District. E-Jurnal Akuntansi, 30(7), 1886-1899.

Mada, S., Kalangi, L., \& Gamaliel, H. (2017). Pengaruh Kompetensi Aparat Pengelola Dana Desa, Komitmen Organisasi Pemerintah Desa, dan Partisipasi Masyarakat Terhadap Akuntabilitas Pengelolaan Dana Desa Di Kabupaten Gorontalo. Jurnal Riset Akuntansi Dan Auditing “Goodwill,” 8(2), 106-115.

Peraturan Pemerintah No. 60 Tahun 2008 tentang Sistem Pengendalian Intern Pemerintal didapat dari https://www.bkp.go.id.(Diakses tanggal 10 juli 2020)

Peraturan Menteri Dalam Negeri No. 11 Tahun 2014 tentang Pengelolaan keuangan Desa. Didapat dari https://www.jogloabang.com/pustaka/permendagri-113-2014-pengelolaan-keuangan-desa. (Diakses tanggal 10 juli 2020)

Peraturan Menteri Dalam Negeri No. 83 Tahun 2015 tentang Pengangkatan dan Pemberhentian Perangkat Desa. Tersedia di : https://ngada.org/bn5-2016.htm.(Diakses tanggal 16 juli 2020

Sweetania, A.M. Caesari, E.P.A. Aprillia, A.F Purwantini, A.H. (2019). Pengaruh Kompetensi, Sistem Pengendalian Internal, Dan Kualitas Penyajian Laporan Keuangan terhadap Akuntabilitas Pemerintah Desa. 1urnal Analisis Bisnis EKonomi. 7(1), 44-56.

Widyatama, A., Novita, L., \& Diarespati, D. (2017). Pengaruh Kompetensi Dan Sistem Pengendalian Internal Terhadap Akuntabilitas Pemerintah Desa Dalam Mengelola Alokasi Dana Desa (Add). Berkala Akuntansi Dan 
Studi Akuntansi \& Keuangan Indonesia

Keuangan Indonesia, 2(2), 1-20.

Yesinia, N.I., Yuliarti, N.., dan Pusoitasari, D. (2018). Analisis Faktor yang Mempengaruhi Akuntabilitas Pengelolaan Alokasi Dana Desa. Jurnal ASET (Akuntansi Riset), 10(1), 105-112.

\section{Lampiran}

Tabel 9. Rangkuman Hasil Pilot Test

\begin{tabular}{|l|l|}
\hline Responden & Masukan/feedback \\
\hline Camat Tanawawo & $\begin{array}{l}\text { Pada point pendidikan terkahir, pendidikan } \\
\text { SMP dihilangkan, dikarenakan tidak sesuai } \\
\text { dengan syarat menjadi pemerintah desa yang } \\
\text { mengakomodir minimal lulusan SMA } \\
\text { sederajat }\end{array}$ \\
\hline Sekertaris Camat & $\begin{array}{l}\text { Pada point kompetensi aparat pengelola desa } \\
\text { (X1), sebaiknya kalimat "saya" diganti } \\
\text { menjadi aparatur desa atau pemerintah desa. }\end{array}$ \\
\hline Mantan Kepala Desa & $\begin{array}{l}\text { Pada point pertanyaan No 2 varaibel } \\
\text { penggunaan aplikasi siskeudes sebaiknya kata } \\
\text { "saya" dihilangkan karena dapat menyebabkan } \\
\text { pengertian berbeda dari responden }\end{array}$ \\
\hline Pemerintah Desa 1 & $\begin{array}{l}\text { Pada point pertanyaan No 13 varaibel sistem } \\
\text { pengendalian internal sebaiknya kata } \\
\text { "pimpinan" dihilangkan dan diganti dengan } \\
\text { "kepala desa" karena dapat menyebabkan } \\
\text { kebingungan dalam menjawab point } \\
\text { pertanyaan tersebut }\end{array}$ \\
\hline Pemerintah Desa 4 & $\begin{array}{l}\text { Tidak ada masukan yang diberikan } \\
\text { Pemerintah Desa 5 }\end{array}$ \\
\hline Tidak ada masukan yang diberikan \\
\hline
\end{tabular}


Tabel 10. Uji Validitas

\begin{tabular}{|c|c|c|c|}
\hline $\begin{array}{l}\text { Indikator } \\
\text { Variabel }\end{array}$ & $\begin{array}{l}\text { Nilai } \\
\text { Sig.level 2(tailed) }\end{array}$ & $\begin{array}{c}\text { Pearson } \\
\text { Correlation }\end{array}$ & $\begin{array}{c}\text { Valid/ Tidak } \\
\text { Valid }\end{array}$ \\
\hline KAPD 1 & 0,014 & 0,814 & Valid \\
\hline KAPD 2 & 0,000 & 0,944 & Valid \\
\hline KAPD 3 & 0,002 & 0,780 & Valid \\
\hline KAPD 4 & 0,000 & 0,944 & Valid \\
\hline KAPD 5 & 0,014 & 0,814 & Valid \\
\hline KAPD 6 & 0,000 & 0,944 & Valid \\
\hline SPI 1 & 0,015 & 0,808 & Valid \\
\hline SPI 2 & 0,004 & 0,883 & Valid \\
\hline SPI 3 & 0,016 & 0,806 & Valid \\
\hline SPI 4 & 0,004 & 0,883 & Valid \\
\hline SPI 5 & 0,016 & 0,806 & Valid \\
\hline SPI 6 & 0,004 & 0,883 & Valid \\
\hline SPI 7 & 0,016 & 0,806 & Valid \\
\hline SPI 8 & 0,004 & 0,883 & Valid \\
\hline SPI 9 & 0,016 & 0,806 & Valid \\
\hline SPI 10 & 0,004 & 0,883 & Valid \\
\hline SPI 11 & 0,016 & 0,806 & Valid \\
\hline SPI 12 & 0,004 & 0,883 & Valid \\
\hline SPI 13 & 0,016 & 0,806 & Valid \\
\hline SPI 14 & 0,004 & 0,883 & Valid \\
\hline $\begin{array}{l}\text { Indikator } \\
\text { Variabel }\end{array}$ & $\begin{array}{l}\text { Nilai } \\
\text { Sig.level 2(tailed) }\end{array}$ & $\begin{array}{c}\text { Pearson } \\
\text { Correlation }\end{array}$ & $\begin{array}{c}\text { Valid/ Tidak } \\
\text { Valid }\end{array}$ \\
\hline PMD 1 & 0,007 & 0,856 & Valid \\
\hline PMD 2 & 0,013 & 0,817 & Valid \\
\hline PMD 3 & 0,028 & 0,761 & Valid \\
\hline PMD 4 & 0,009 & 0,841 & Valid \\
\hline PMD 5 & 0,007 & 0,856 & Valid \\
\hline PMD 6 & 0,009 & 0,838 & Valid \\
\hline PMD 7 & 0,007 & 0,856 & Valid \\
\hline PMD 8 & 0,009 & 0,838 & Valid \\
\hline PAS 1 & 0,010 & 0,806 & Valid \\
\hline PAS 2 & 0,021 & 0,883 & Valid \\
\hline PAS 3 & 0,017 & 0,806 & Valid \\
\hline PAS 4 & 0,005 & 0,883 & Valid \\
\hline PAS 5 & 0,010 & 0,806 & Valid \\
\hline PAS 6 & 0,021 & 0,883 & Valid \\
\hline PAS 7 & 0,017 & 0,806 & Valid \\
\hline PAS 8 & 0,005 & 0,883 & Valid \\
\hline AKPD 1 & 0,002 & 0,905 & Valid \\
\hline AKPD 2 & 0.005 & 0,870 & Valid \\
\hline AKPD 3 & 0,002 & 0,905 & Valid \\
\hline AKPD 4 & 0,005 & 0,870 & Valid \\
\hline AKPD 5 & 0,002 & 0,905 & Valid \\
\hline AKPD 6 & 0,005 & 0,870 & Valid \\
\hline AKPD 7 & 0,002 & 0,905 & Valid \\
\hline AKPD 8 & 0,002 & 0,905 & Valid \\
\hline
\end{tabular}

Sumber: Data diolah (2020). 
Studi Akuntansi \& Keuangan Indonesia

Lampiran: Kuesioner Penelitian

\section{Petunjuk Pengisian}

A Memberikan tanda $(\sqrt{ })$ atau $(X)$ pada alternatif pilihan jawaban dari pernyataan yang ada sesuai dengan pendapat Bapak/Ibu/Saudara/i, jika menurut Bapak/Ibu/Saudara/i tidak ada jawaban yang tepat, maka jawaban dapat diberikan pada pilihan paling mendekati. Skor jawaban adalah sebagai berikut:

Skor 1 = STS (Sangat Tidak Setuju)

$$
\begin{aligned}
& 2=\text { TS }(\text { Tidak Setuju) } \\
& 3=\text { KS (Kurang Setuju) } \\
& 4=\text { S (Setuju) } \\
& 5=\text { SS (Sangat Setuju) }
\end{aligned}
$$

B Tidak ada jawaban benar atau salah, untuk itu dimohon untuk memberikan jawaban yang objektif sesuai dengan kenyataan di lapangan.

\section{Identitas Responden}
A. Nama
B. Jabatan

C. Jenis Kelamin

D. Usia

E. Masa Kerja

F. Pendidikan Terakhir

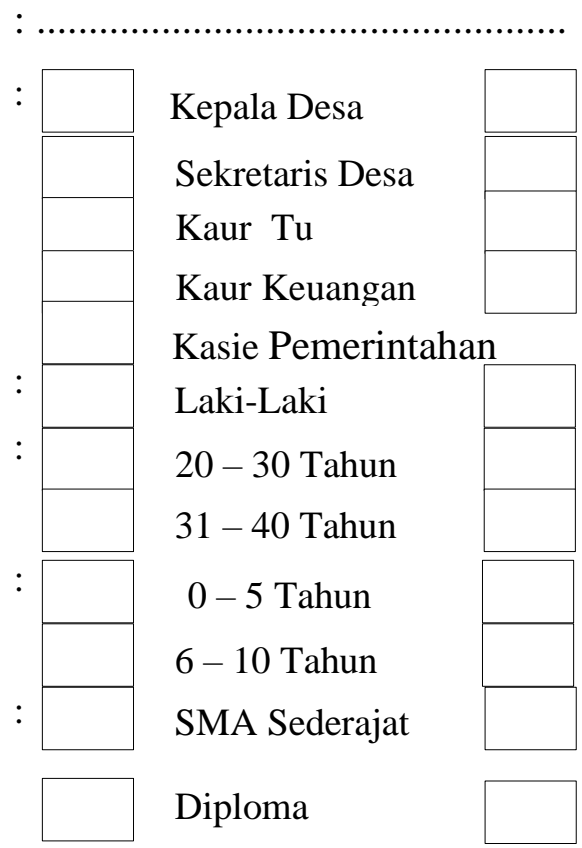

(Boleh tidak diisi)

Kasie Kesejahteraan

Kasie Pelayanan

Kepala Dusun

BPD

Perempuan

41 - 50 Tahun

51 Tahun keatas

11 - 15 Tahun

15 Tahun keatas

S1

S2

\section{INDIKATOR VARIABEL}

\section{A. Akuntabailitas Pengelolalaan Keuangan Desa (Y)}

\begin{tabular}{|l|l|l|l|l|l|l|}
\hline NO. & Pernyataan & STS & TS & N & S & SS \\
\hline 1. & $\begin{array}{l}\text { Aparatur desa dengan jujur membuat laporan keuangan dana } \\
\text { desa. }\end{array}$ & & & & & \\
\hline 2. & $\begin{array}{l}\text { Aparatur desa memberikan informasi kepada masyarakat } \\
\text { secara terbuka dan jujur mengenai pengelolaan dana desa. }\end{array}$ & & & & & \\
\hline 3. & $\begin{array}{l}\text { Aparatur desa melaporkan semua pengelolaan dana desa sesuai } \\
\text { dengan pencatatan yang telah dilakukan. }\end{array}$ & & & & & \\
\hline 4. & $\begin{array}{l}\text { Aparatur desa melaporkan pengelolaan dana desa sebagai } \\
\text { pertangunggjawabannya atas dana desa secara tepat waktu. }\end{array}$ & & & & & \\
\hline 5. & $\begin{array}{l}\text { Aparatur desa melaporkan laporan pengelolaan dana desa } \\
\text { dengan prosedur yang telah di tentukan. }\end{array}$ & & & & \\
\hline
\end{tabular}


Studi Akuntansi \& Keuangan Indonesia

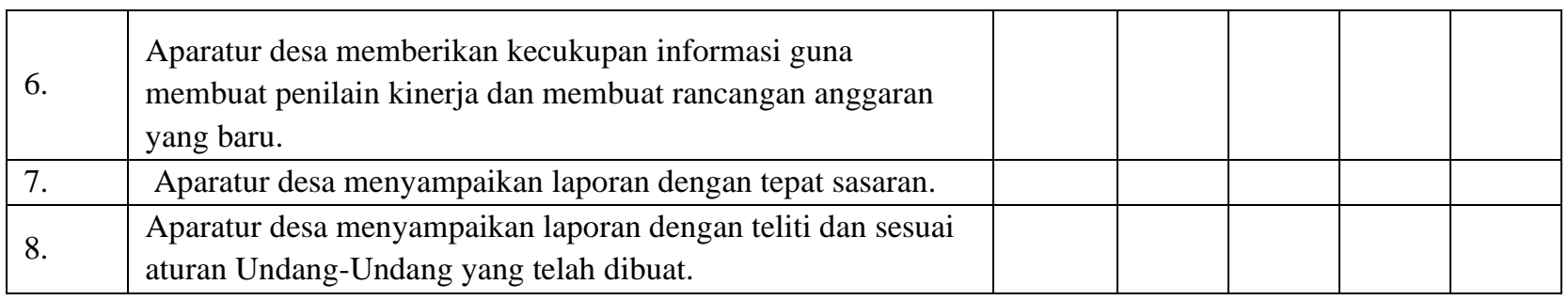

\section{B. Kompetensi Aparat Pengelola Desa (XI)}

\begin{tabular}{|c|c|c|c|c|c|c|}
\hline No & Pernyataan & STS & TS & KS & $\mathbf{S}$ & SS \\
\hline 1. & $\begin{array}{l}\text { Saya memahami Permendagri No } 113 \text { Tahun } 2014 \text { tentang } \\
\text { Pengelolaan Keuangan Desa }\end{array}$ & & & & & \\
\hline 2. & $\begin{array}{l}\text { Saya memahami tugas pokok, fungsi dan uraian tugas saya } \\
\text { sebagai penyusun laporan keuangan }\end{array}$ & & & & & \\
\hline 3. & $\begin{array}{l}\text { Saya sebagai aparat desa melakukan pembukuan mendasar } \\
\text { pada Standar Akuntansi Pemerintahan (SAP) }\end{array}$ & & & & & \\
\hline 4. & $\begin{array}{l}\text { Saya sering mengikuti pelatihan teknis untuk meningkatkan } \\
\text { kemampuan terkait pengelolaan keuangan desa }\end{array}$ & & & & & \\
\hline 5. & $\begin{array}{l}\text { Saya sebagai aparat desa mempunyai inisiatif untuk } \\
\text { mengerjakan pekerjaan yang ada }\end{array}$ & & & & & \\
\hline 6. & $\begin{array}{l}\text { Saya selalu bekerja dengan mengedepankan etika dan kode } \\
\text { etik sebagai seorang pegawai }\end{array}$ & & & & & \\
\hline
\end{tabular}

\section{Sistem Pengendalian Internal (X2)}

\begin{tabular}{|c|l|l|l|l|l|l|}
\hline NO. & \multicolumn{1}{|c|}{ PTS } & TS & N & S & SS \\
\hline 1. & $\begin{array}{l}\text { Pemerintahan desa harus memiliki struktur organisasi yang } \\
\text { baik. }\end{array}$ & & & & \\
\hline 2. & Aparatur desa memahami tugas dan peran masing-masing. & & & & & \\
\hline 3. & $\begin{array}{l}\text { Setiap pemasukan dan pengeluaran dari dana desa, aparatur desa } \\
\text { harus mempunyai bukti transaksinya. }\end{array}$ & & & & \\
\hline 4. & $\begin{array}{l}\text { Aparatur desa wajib mengkomunikasikan setiap kegiatan yang } \\
\text { berkaitan dengan dana desa. }\end{array}$ & & & & \\
\hline 5. & $\begin{array}{l}\text { Perlunya pengetahuan yang harus dimiliki oleh setiap apatur } \\
\text { desa tentang pengendalian internal. }\end{array}$ & & & \\
\hline 6. & $\begin{array}{l}\text { Pimpinan desa harus mampu memberikan arahan untuk selalu } \\
\text { mengedepankan tanggungjawab dan kejujuran dalam } \\
\text { menjalankan tugas. }\end{array}$ & & & & \\
\hline 7. & $\begin{array}{l}\text { Wewenang yang diberikan kepada aparatur desa harus cukup } \\
\text { dan sesuai dengan tingkat pertanggungjawabannya. }\end{array}$ & & & \\
\hline 8. & $\begin{array}{l}\text { Aparatur desa harus bisa melakukan penilaian terhadap setiap } \\
\text { pekerjaan. }\end{array}$ & & & & \\
\hline 9. & $\begin{array}{l}\text { Aparatur desa yang mengelola dana desa memberikan batasan } \\
\text { akses terhadap dana desa yang dimiliki. }\end{array}$ & & & \\
\hline 10. & $\begin{array}{l}\text { Setiap transaksi harus memiliki catatan dan dicatat dengan } \\
\text { benar. }\end{array}$ & & & & \\
\hline 11. & $\begin{array}{l}\text { Aparatur desa melakukan pengamanan terhadap segala aset } \\
\text { yang digunakan untuk kepentingan publik. }\end{array}$ & & & & \\
\hline 12. & $\begin{array}{l}\text { Aparatur desa memberikan informasi dan mengkomunikasikan } \\
\text { tentang sistem pengendalian internal yang relevan kepada pihak } \\
\text { lain. }\end{array}$ & & & & \\
\hline 13. & $\begin{array}{l}\text { Pimpinan harus selalu memantau setiap pekerjaan yang } \\
\text { dilakukan. }\end{array}$ & & & & \\
\hline 14. & $\begin{array}{l}\text { Aparatur desa harus melakukan evaluasi berkelanjutan guna } \\
\text { memperbaiki setiap pekerjaan yang telah dilakukan. }\end{array}$ & & & & \\
\hline
\end{tabular}




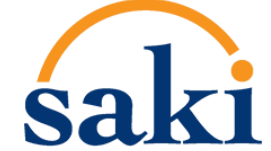

Studi Akuntansi \& Keuangan Indonesia

\section{Partisipasi Masyarakat (X3)}

\begin{tabular}{|c|l|c|c|c|c|c|}
\hline No & \multicolumn{1}{|c|}{ Pernyataan } & STS & TS & KS & S & SS \\
\hline 1. & $\begin{array}{l}\text { Masyarakat desa terlibat dalam pengambilan keputusan } \\
\text { program-program desa }\end{array}$ & & & & \\
\hline 2. & $\begin{array}{l}\text { Masyarakat desa memberikan masukan kepada BPD dan } \\
\text { Pemerintah Desa }\end{array}$ & & & & & \\
\hline 3. & $\begin{array}{l}\text { Masyarakat desa membuat dan mengusulkan Rencana } \\
\text { Anggaran alternatif (tandingan) terhadap Rancangan } \\
\text { anggaran desa yang diajukan oleh Kepala desa dan/atau BPD }\end{array}$ & & & & \\
\hline 4. & $\begin{array}{l}\text { Masyarakat desa terlibat aktif dalam Rapat Dengar Pendapat } \\
\text { atau Rapat Paripurna Pembahasan dan Penetapan anggaran } \\
\text { desa }\end{array}$ & $\begin{array}{l}\text { Masyarakat desa melakukan pengawasan pelaksanaan } \\
\text { anggaran desa }\end{array}$ & & & & \\
\hline 6. & $\begin{array}{l}\text { Masyarakat desa memberikan penilaian pelaksanaan } \\
\text { anggaran desa }\end{array}$ & & & & \\
\hline 7. & $\begin{array}{l}\text { Masyarakat desa memberikan penghargaan atas keberhasilan } \\
\text { Pemerintah Desa dalam pengelolaan anggaran desa }\end{array}$ & & & & \\
\hline 8. & $\begin{array}{l}\text { Masyarakat desa memberikan pengahargaan atas } \\
\text { keberhasilan BPD dalam pengawasan (kontrol) pelaksanaan } \\
\text { anggaran desa }\end{array}$ & & & & \\
\hline
\end{tabular}

\section{E. Penggunaan Aplikasi Siskeudes (X4)}

\begin{tabular}{|c|l|l|l|l|l|l|}
\hline No & Pernyataan & STS & TS & KS & S & SS \\
\hline 1. & $\begin{array}{l}\text { Proses akuntansi sejak awal transaksi pada pemerintah desa } \\
\text { telah dilaksanakan secara komputerisasi dan menggunakan } \\
\text { program yang mudah digunakan. }\end{array}$ & & & & \\
\hline 2. & $\begin{array}{l}\text { Dengan menggunakan aplikasi siskeudes, proses penyusunan } \\
\text { laporan keuangan pada pemerintah desa saya menjadi lebih } \\
\text { cepat daripada dikerjakan secara manual. }\end{array}$ & $\begin{array}{l}\text { Deban menggunakan aplikasi siskeudes, segala proses } \\
\text { dokumentasi, administrasi dan pengolahan data transaksi } \\
\text { keuangan telah menunjukkan hasil lebih konsisten. }\end{array}$ & & & & \\
\hline 4. & $\begin{array}{l}\text { Aplikasi siskeudes yang digunakan mempunyai format yang } \\
\text { standar dan tidak berubah-ubah. }\end{array}$ & & & \\
\hline 5. & $\begin{array}{l}\text { Dengan menggunakan aplikasi siskeudes segala proses } \\
\text { akuntansi keuangan di pemerintah desa telah menunjukkan } \\
\text { hasil yang lebih akurat. }\end{array}$ & $\begin{array}{l}\text { Dengan menggunakan aplikasi siskeudes, segala proses } \\
\text { akuntansi keuangan di pemerintah desa dapat terdeteksi serta } \\
\text { meminimalisir kesalahan sekecil mungkin. }\end{array}$ & & & & \\
\hline 7. & $\begin{array}{l}\text { Dengan menggunakan aplikasi siskeudes telah menghasilkan } \\
\text { laporan keuangan pemerintahan desa sesuai dengan ketentuan } \\
\text { Permendagri No 113 Tahun 2014 tentang pengelolaan } \\
\text { keuangan desa. }\end{array}$ & & & & \\
\hline 8. & $\begin{array}{l}\text { Informasi keuangan yang telah dihasilkan dari aplikasi } \\
\text { siskeudes dapat dipercaya dan andal. }\end{array}$ & & & & \\
\hline
\end{tabular}

